\title{
P-glycoprotein: from genomics to mechanism
}

\author{
Suresh V Ambudkar*,1, Chava Kimchi-Sarfaty ${ }^{1}$, Zuben E Sauna ${ }^{1}$ and Michael M Gottesman*,1 \\ ${ }^{1}$ Laboratory of Cell Biology, Center for Cancer Research, National Cancer Institute, NIH, Bethesda, MD 20892, USA
}

\begin{abstract}
Resistance to chemically different natural product anticancer drugs (multidrug resistance, or MDR) results from decreased drug accumulation, resulting from expression of one or more ATP-dependent efflux pumps. The first of these to be identified was P-glycoprotein (P-gp), the product of the human MDR1 gene, localized to chromosome 7q21. P-gp is a member of the large ATP-binding cassette (ABC) family of proteins. Although its crystallographic 3-D structure is yet to be determined, sequence analysis and comparison to other $\mathrm{ABC}$ family members suggest a structure consisting of two transmembrane (TM) domains, each with six TM segments, and two nucleotide-binding domains. In the epithelial cells of the gastrointestinal tract, liver, and kidney, and capillaries of the brain, testes, and ovaries, P-gp acts as a barrier to the uptake of xenobiotics, and promotes their excretion in the bile and urine. Polymorphisms in the MDR1 gene may affect the pharmacokinetics of many commonly used drugs, including anticancer drugs. Substrate recognition of many different drugs occurs within the TM domains in multipleoverlapping binding sites. We have proposed a model for how ATP energizes transfer of substrates from these binding sites on P-gp to the outside of the cell, which accounts for the apparent stoichiometry of two ATPs hydrolysed per molecule of drug transported. Understanding of the biology, genetics, and biochemistry of P-gp promises to improve the treatment of cancer and explain the pharmacokinetics of many commonly used drugs.
\end{abstract}

Oncogene (2003) 22, 7468-7485. doi:10.1038/sj.onc.1206948

Keywords: ABC transporter; multidrug resistance; Pglycoprotein; drug transport; ATP hydrolysis; catalytic cycle; polymorphism

Introduction: the phenomenon of multidrug resistance

The use of chemotherapy to treat cancer is limited by the development of resistant cancer cell variants. Resistance can occur to individual cytotoxic drugs usually by alterations in the targets for these drugs, but can also occur more broadly to many different drugs with different chemical structures and different mechanisms of action. This latter form of resistance is called multidrug resistance, or MDR. MDR appears to be the major

*Correspondence: SV Ambudkar and MM Gottesman, Laboratory of Cell Biology, Center for Cancer Research, National Cancer Institute, NIH, 37 Convent Drive, Building 37, Room 1A-09, Bethesda, MD 20892-4254, USA; E-mail: ambudkar@helix.nih.gov reason for failure of chemotherapy in cancer, since multiple chemotherapeutic drugs of different classes are used to treat most cancers. Many different mechanisms of MDR have been elucidated, including alterations in cell cycle checkpoints, failure of apoptotic mechanisms, repair of damaged cellular targets, and reduced drug accumulation (reviewed in Borst and Elferink, 2002; Gottesman, 2002). Of these mechanisms, reduced drug accumulation has been studied in most detail, and appears to be a very common mechanism of MDR both in vitro and in vivo.

To understand how drug accumulation can be reduced in cancer cells, it is first necessary to examine how drugs get into cells. There are basically two mechanisms of drug uptake. For water-soluble, hydrophilic drugs such as cisplatin, nucleoside analogue and antifolates, drugs cannot cross the plasma membrane unless they piggyback on existing transporters or carriers, or enter through hydrophilic channels in the membrane. Resistance to such drugs resulting from decreased accumulation occurs because of individual mutations in the carriers, which produce single-agent resistance. MDR can occur because of a generalized defect in the localization of transporters and carriers on the cell surface, as is seen when selecting for cisplatin resistance which results in MDR to many different hydrophilic anticancer drugs and other small molecules (Shen et al., 1998). For hydrophobic drugs, such as the natural products vinblastine, vincristine, doxorubicin, daunorubicin, actinomycin $\mathrm{D}$, etoposide, teniposide, and paclitaxel, entry occurs by diffusion across the plasma membrane, without any specific drug carriers. The only way to keep such drugs out of cells is by activation of energy-dependent transport systems (reviewed in Ambudkar et al., 1999). The first of these transporters, to be identified and characterized known as the ATP-binding cassette $(\mathrm{ABC})$ transporters because of their homologous ATP-binding domains, was P-glycoprotein (P-gp), the product of the human $M D R 1$ gene. Subsequently, other members of this family of transporters such as MRP1 (ABCC1) and MXR (ABCG2) have been shown to be capable of conferring MDR by virtue of energydependent drug efflux (reviewed in Litman et al., 2001; Borst and Elferink, 2002; Gottesman et al., 2002).

\section{$A B C$ transporters and multidrug resistance}

To date, 48 different $\mathrm{ABC}$ transporters have been identified in the human genome, divided into seven different classes $(A-G)$ based on sequence similarities. Members of four of these classes (A, B, C, and G) have 
been clearly shown to confer drug resistance on cultured cells (Table 1). Although all share a similar ABC, their domain structures are organized somewhat differently, with different numbers and locations of TM domains (Gottesman, 2002). All but one of these transporters contain two ABCs in a single molecule; ABC G2, initially identified as a mitoxantrone-resistance gene (MXR or BCRP, breast cancer resistance protein), has only one TM domain and one $\mathrm{ABC}$, and is assumed to function as a dimer (Ejendal and Hrycyna, 2002). P-gp (MDR1 or $\mathrm{ABC} \mathrm{B} 1$ ), the subject of this review, consists of two TM domains and two ABCs (see Figures 1, 3).

P-gp was the first of the human ABC transporters to be described (Chen et al., 1986). Subsequently, MRP1 (ABC C1) was isolated from an MDR lung cancer cell line where MDR1 was not expressed (Cole et al., 1992). MRP1 has similar transport specificity to MDR1, but drugs are frequently conjugated with glutathione and other anions, or are cotransported with glutathione (reviewed in Loe et al., 1996; Borst et al., 1999). P-gp transports neutral and cationic hydrophobic compounds, whereas MRP1 can transport anionic compounds. P-gp is expressed in only a limited number of tissues with barrier function, including epithelia of the liver, kidney, small and large intestine and capillary endothelial cells in brain, ovary, and testis, while MRP1 is expressed in most of the tissues. Both of these transporters have been implicated in the resistance of various cancers to chemotherapy (see below).

There are currently 10 members of the MRP1 family known, and at least seven of them (MRP1, 2, 3, 4, 5, 6, and 7) have been shown to confer resistance to one or more drugs used to treat cancer (see Table 1). Only MDR1 and MRP1 have been shown to have likely significance in clinical drug resistance, but the others have not been sufficiently studied to role out a possible role for them as well. The half-transporter ABC G2 (MXR, BCRP, ABC-P) confers resistance to a broad range of hydrophobic anticancer drugs similar to MDR1 and MRP1, including doxorubicin, daunorubicin, mitoxantrone and topotecan (Brangi et al., 1999; Litman et al., 2000), especially when the Arg at position 482 is substituted by Thr or Gly. In addition, wild-type ABCG2 appears to confer resistance to methotrexate (Volk et al., 2002). ABC B1 (P-gp) and ABC G2 (MXR) are commonly expressed in hematopoietic and other stem cells (Bunting, 2002; Zhou et al., 2002). Other transporters which have been demonstrated to confer drug resistance in vitro include $\mathrm{ABC} \mathrm{A} 2$ (resistance to the nitrogen mustard derivative of estradiol, estramustine), and ABC B11 (SP-gp) (resistance to paclitaxel) (Childs et al., 1998).

\section{Clinical relevance of expression of $A B C$ transporters in cancer cells}

To demonstrate the involvement of an ABC transporter in resistance to anticancer drugs, the following criteria must be met: (1) The cancer must express the transporter at levels that have been shown in vitro to confer resistance to the drugs or drugs in question. (2) The level of expression of the transporter should predict the degree of drug resistance; (3) During the course of clinical treatment, development of drug resistance should parallel the increased expression of the transporter. (4) Agents which inhibit the function of the transporter, in instances in which the transporter is expressed and no other resistance mechanisms are known to be acting, should reverse the resistance. (5) Use of inhibitors of transporters as part of chemotherapy should produce a survival advantage.

Owing to the difficulty in accurately measuring ABC transporters in cancer cells due to the crossreactivity of antibodies, samples contaminated with normal tissue, and lack of meaningful controls (pre- or post-treatment tumor samples, or other evidence of what baseline expression of the transporter might be), the clinical studies conducted to date have all failed to provide convincing evidence, for or against a clinical role for the expression of ABC transporters in anticancer drug resistance. However, many studies strongly suggest a role for MDR1 in MDR for some cancers, and a few studies implicate MRP1. MDR1 is expressed in acute myelogenous leukemia in $1 / 3$ of the patients at the time of first diagnosis, and in more than $50 \%$ of patients at first relapse; the level of expression at presentation is sufficient to confer resistance based on in vitro assays of $\mathrm{P}$-gp transport function, and correlates with the likelihood of relapse (Leith et al., 1999). Addition of the P-gp inhibitor cyclosporin A to the treatment regimen for AML improves the chance of remission and improves survival (List et al., 2001). Thus, for AML, all of the criteria indicating the clinical relevance of P-gp in MDR are met.

MDR 1 is also expressed at high levels in many other tumors under three different circumstances: (1) cancers derived from epithelial tissues that normally express Pgp including the kidney, liver, and colon cancer; (2) cancers in which P-gp levels were low at presentation, but after chemotherapy, cancers recurred, which now express P-gp such as leukemias, lymphomas, and multiple myeloma; and (3) cancers in which the development of the tumor appears to be associated with the turning on of expression of P-gp, including chronic myelogenous leukemia in blast crisis and neuroblastoma (Goldstein et al., 1989). Attempts to demonstrate reversal of drug resistance in some of these tumors have not been successful, in some cases because other forms of MDR may also be expressed in these cancers, in other cases because the expression of P-gp was not demonstrated in each of the treated patients, or because the numbers of patients involved were small and responses could not reach statistical significance.

As noted, MRP1 is also expressed at high levels in many cancers, especially leukemias, esophageal carcinomas, and non-small-cell lung cancers (Nooter et al., 1995). In no case is there evidence that resistance correlates with increasing levels of MRP1, or evidence that inhibition of MRP1 reverses drug resistance in cancer. In addition, MRP1 can be found in virtually all cancers, because of its ubiquitous expression in human cancers. Although it may contribute to the baseline resistance of all cells, whether it plays a specific role in the MDR of human cancers remains to be demon- 
Table 1 Tissue localization and likely functions of $\mathrm{ABC}$ drug transporters

\begin{tabular}{|c|c|c|c|c|c|}
\hline Common name & $\begin{array}{l}\text { Systematic } \\
\text { name }\end{array}$ & Tissue & Nonchemotherapy substrates & $\begin{array}{l}\text { Chemotherapy substrates } \\
\text { (known and suspected) }\end{array}$ & References \\
\hline $\mathrm{ABCA} 2$ & $\mathrm{ABCA} 2$ & Brain, monocytes & Steroid derivatives, lipids & Estramustine & $\begin{array}{l}\text { Dean et al. (2001); Laing et al. (1998); } \\
\text { Vulevic et al. (2001) }\end{array}$ \\
\hline P-gp/MDR1 & $\mathrm{ABCB} 1$ & $\begin{array}{l}\text { Intestine, liver, } \\
\text { kidney placenta, } \\
\text { blood-brain barrier }\end{array}$ & $\begin{array}{l}\text { Neutral and cationic organic } \\
\text { compounds, many commonly } \\
\text { used drugs }\end{array}$ & $\begin{array}{l}\text { Doxorubicin, daunorubicin, } \\
\text { vincristine, vinblastine, } \\
\text { actinomycin-D, paclitaxel, } \\
\text { docetaxel, etoposide, teniposide, } \\
\text { bisantrene, homoharringtonine, } \\
\text { Gleevec (STI-571) }\end{array}$ & Ambudkar et al. (1999) \\
\hline MDR2 & $\mathrm{ABCB} 4$ & Liver & $\begin{array}{l}\text { Phosphatidylcholine, some } \\
\text { hydrophobic drugs }\end{array}$ & Paclitaxel, vinblastine & $\begin{array}{l}\text { Smit }(1993, \# 356) ; \text { Borst }(2000, \# 308) ; \\
\text { Ruetz }(1994, \# 351) \text {; de Vree }(1998, \# 315)\end{array}$ \\
\hline MRP1 & $\mathrm{ABCCl}$ & All tissues & $\begin{array}{l}\text { Glutathione and other conjugates, } \\
\text { organic anions, leukotriene C4 }\end{array}$ & $\begin{array}{l}\text { Doxorubicin, epirubicin, etoposide, } \\
\text { vincristine, methotrexate }\end{array}$ & $\begin{array}{l}\text { Borst et al. (2000); Cole et al. (1992); } \\
\text { Jedlitschky et al. (1996); Loe et al. (1998); } \\
\text { Muller et al. (1994) }\end{array}$ \\
\hline MRP2, cMOAT & $\mathrm{ABCC} 2$ & Liver, kidney, intestine & $\begin{array}{l}\text { Similar to MRP1, nonbile-salt } \\
\text { organic anions }\end{array}$ & $\begin{array}{l}\text { Methotrexate, etoposide, doxorubicin, } \\
\text { cisplatin, vincristine, mitoxantrone }\end{array}$ & $\begin{array}{l}\text { Borst (2000, \#307); Paulusma (1996, \#392); } \\
\text { Ito (1997, \#390); Kartenbeck (1996, \#391); } \\
\text { Paulusma (1997, \#389) }\end{array}$ \\
\hline MRP3 & $\mathrm{ABCC} 3$ & $\begin{array}{l}\text { Pancreas, kidney, intestine, } \\
\text { liver, adrenal glands }\end{array}$ & $\begin{array}{l}\text { Glucuronate and glutathione } \\
\text { conjugates, bile acids }\end{array}$ & $\begin{array}{l}\text { Etoposide, teniposide, methotrexate, } \\
\text { cisplatin, vincristine, doxorubicin }\end{array}$ & Kool (1999, \#374); Belinsky, (1999, \#371) \\
\hline MRP4 & $\mathrm{ABCC} 4$ & $\begin{array}{l}\text { Prostate, testis, ovary, } \\
\text { intestine, pancreas, lung }\end{array}$ & $\begin{array}{l}\text { Nucleoside analogues, } \\
\text { organic anions }\end{array}$ & Methotrexate, thiopurines & Chen (2001, \#370); Schuetz (1999, \#383) \\
\hline MRP5 & ABCC5 & Most tissues & $\begin{array}{l}\text { Nucleoside analogues, } \\
\text { cyclic nucleotides, } \\
\text { organic anions }\end{array}$ & 6-Mercaptopurine, 6-thioguanine & $\begin{array}{l}\text { Wijnholds }(2000, \# 378) \text {; } \\
\text { Jedlitschky }(2000, \# 376)\end{array}$ \\
\hline MRP6 & ABCC6 & Liver, kidney & Anionic cyclic pentapeptide & Unknown & $\begin{array}{l}\text { Struk (2000, \#377); Bergen }(2000, \# 380) ; \\
\text { Ringpfeil (2000, \#381); Le Saux }(2000, \# 379) \text {; } \\
\text { Kool (1999, \#386) }\end{array}$ \\
\hline MRP7 & $\mathrm{ABCC} 10$ & Liver, heart, kidney & $\begin{array}{l}\text { Glutathione conjugates, } \\
\text { lipophilic anions }\end{array}$ & Unknown & Chen et al. (2003) \\
\hline $\begin{array}{l}\text { MXR, BCRP, } \\
\text { ABC-P }\end{array}$ & ABCG2 & $\begin{array}{l}\text { Placenta, intestine, } \\
\text { breast, liver }\end{array}$ & Prazosin & $\begin{array}{l}\text { Doxorubicin, daunorubicin, } \\
\text { mitoxantrone, topotecan, SN-38 }\end{array}$ & $\begin{array}{l}\text { Miyake (1999,\#163); Doyle (1998, \#164); } \\
\text { Allikmets (1998, \#198); Honjo (2001, \#401); } \\
\text { Komatani }(2001, \# 396) \text {; Maliepaard }(2001, \# 375)\end{array}$ \\
\hline BSEP, SP-gp & ABCB11 & Liver & Bile salts & Paclitaxel & $\begin{array}{l}\text { Childs (1998, \#397); Gerloff (1998, \#384); } \\
\text { Lecureur }(2000, \# 382) \text {; Strautnieks (1998, \#387); } \\
\text { Wang (2001, \#385) }\end{array}$ \\
\hline
\end{tabular}


strated. The other ABC transporters capable of conferring MDR have not yet been evaluated in clinical samples (Leonard et al., 2002).

\section{Polymorphisms of the MDR1 gene: genetic studies of the MDR1 gene}

The significant role of P-gp in drug pharmacokinetics is suggested by its location in the mucosa of the small and large intestine, at blood-brain barrier sites, in capillary endothelial cells of the testis, in biliary hepatocytes, in the adrenal gland, and in proximal tubules of the kidney (Fojo et al., 1987). Data from $m d r$ knockout transgenic mice also strongly support the role of $M D R 1$ in drug absorption, disposition, elimination, and detoxification pathways (Schinkel, 1997; Johnson et al., 2001). Extensive research has been done on the pharmacological function of $M D R 1$, but only recently have new studies reported several different single-nucleotide polymorphisms (SNPs), which occur as a result of singlenucleotide substitutions, in the human MDR1 coding region. Among the several reasons why gathering information on MDR 1 SNPs is the focus of many recent studies are: (1) defining the relationship between the SNPs and MDR1 function will complement our knowledge about structure-function relationships; (2) the same approach will add to our knowledge about the role of P-gp in cancer cells, especially in resistant cancers if any correlations between polymorphisms and altered cellular pharmacokinetics are found; (3) since $M D R 1$ is a very well-conserved gene (Konings and Poelarends, 2002), studying its SNPs will broaden our understanding about the evolution of this gene; (4) evidence of a relationship between a specific $M D R 1$ haplotype and altered pharmacokinetics may make it possible to predict individual sensitivity to the many drugs which are $M D R 1$ substrates.

Various polymorphisms of the MDR1 gene with different frequencies in distinct ethnic groups

The $M D R 1$ gene comprises 28 exons ranging in size from 49 to $587 \mathrm{bp}$, and the cDNA spans $4.5 \mathrm{~kb}$. A methodical screening for polymorphisms of the entire $M D R 1$ gene, performed by Hoffmeyer et al. (2000) on a healthy Caucasian population, revealed 15 different SNPs in exons and introns. In recent reviews (Brinkmann et al., 2001; Saito et al., 2002; Evans and McLeod, 2003; Schwab et al., 2003), a total of 50 SNPs and three insertion/deletion polymorphisms have been reported in the $M D R 1$ gene. Some of the polymorphisms in the $M D R 1$ gene are 'silent', and cause no amino-acid change (for example: Gly412Gly, or at intron 17, intervening sequence 17 (IVS-17) (IVS-17 A137G)), but some are found to change an amino acid (for example: A61G, T307C, G1199A, and G2677T). Figure 1 shows the location of the reported SNPs which affect the MDR1

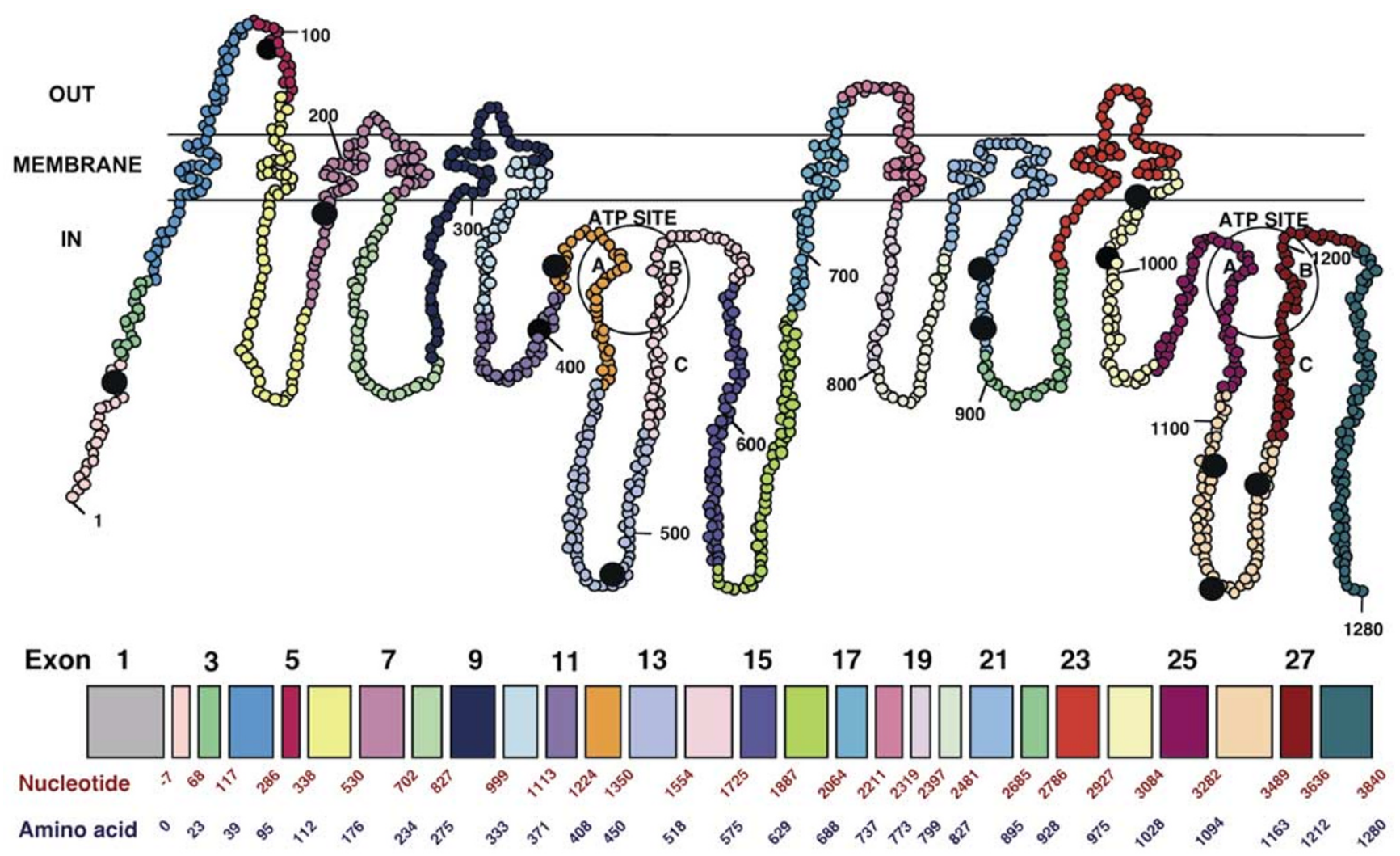

Figure 1 Schematic representation showing the distribution of $M D R 1$ SNPs, which affect the coding sequence, on the predicted 2-D structural model of P-gp. At the bottom, 28 exons of the $M D R 1$ gene are shown, and the region of $\mathrm{P}$-gp encoded by a given exon is also highlighted in a same color on the predicted 2-D P-gp structure. The black-filled circles show the location of the reported SNPs 
coding sequence (exons). The data assembled in Figure 1 are based on the SNPs reviewed here, on the published intron/exon boundaries (Chen et al., 1990), and on the predicted 2-D structural model of P-gp, according to studies from our lab (Gottesman and Pastan, 1988). As shown in Figure 1, some of the reported polymorphisms result in amino-acid changes located in exons 2, 5, 11, 21 , and 24. Interestingly, three of these exons encode amino acids located in the transmembrane domains (5, 21, and 24), one in the first intracellular domain of P-gp (exon 2), and one very close to the ATP-binding site (exon 11). Table 2 summarizes the polymorphisms which are located in exons.

Comparison between different polymorphism studies reveals a variation in frequencies of the heterozygous or homozygous genotypes among different populations, which might be explained by some disadvantages of a specific genotype in the particular population. For example, a frequency of $37.5 \%$ homozygosity for the $\mathrm{T}$ allele was reported, which is the predominant sequence in position 1236, exon 12 among 48 unrelated Japanese healthy individuals (Ito et al., 2001). However, a frequency of $13.3 \%$ homozygosity for the same allele was found in Caucasians (Hoffmeyer et al., 2000). Another explanation for the same phenomenon is that the Caucasian white population was undefined or not divided into specific ethnic groups (Hoffmeyer et al., 2000), while other studies investigated narrower populations (Decleves et al., 2000; Cascorbi et al., 2001).

Interestingly, different variants were found for the location of 2677-Ser893: Cascorbi and associates found the $\mathrm{G}$ allele at a frequency of $56.4 \%$ (893Ala), the $\mathrm{T}$ allele in $41.6 \%$ (893Ser), and the A allele (893Thr) in $1.9 \%$ of 461 white individuals (Cascorbi et al., 2001). This may be due to the presence of a repetitive DNA sequence, resulting in a failure of sequencing at this position, which results in different predicted amino acids.

\section{No altered drug pharmacokinetics was found in vitro in the five most common MDR1-coding polymorphisms}

We determined whether common coding polymorphisms affect the function of P-gp, and/or whether polymorphic variants are linked to altered drug pharmacokinetics, testing the assumption that if functional significant polymorphisms of $M D R 1$ exist, they would have a large impact on drug absorption, and on the blood levels of drugs which are P-gp substrates (KimchiSarfaty et al., 2002). We investigated the effect of the five most common coding polymorphisms on P-gp function: A61G, T307C, G1199A, G2677T, and G2995A. Using a transient Vaccinia expression system for P-gp which was wild-type or carried each of these polymorphisms introduced by site-directed mutagenesis, we were able to demonstrate the cell-surface expression of P-gp variants (using monoclonal antibody MRK-16) (Figure 2, panel a) as well as semiquantitative functional activity, using six different fluorescent substrates: bodipy-FL-verapamil, bodipy-FL-vinblastine, calceinAM, bodipy-FL-prazosin, bisantrene, bodipy-FL-forskolin, and daunorubicin (four of them are presented in
Table 2 Common $M D R 1$ exonic polymorphisms

\begin{tabular}{|c|c|c|c|}
\hline $\begin{array}{l}\text { Exon } \\
\text { number }\end{array}$ & $\begin{array}{l}\text { Polymorphic } \\
\text { nucleotide } \\
\text { variant }\end{array}$ & $\begin{array}{l}\text { Change in } \\
\text { amino acid }\end{array}$ & References \\
\hline 1 & -145 & - & Ito et al. (2001) \\
\hline 1 & -129 & - & $\begin{array}{l}\text { Hoffmeyer et al. (2000); } \\
\text { Tanabe et al. (2001) }\end{array}$ \\
\hline 2 & 61 & N21D & $\begin{array}{l}\text { Cascorbi et al. (2001); } \\
\text { Decleves et al. (2000); } \\
\text { Hoffmeyer et al. (2000); } \\
\text { Kim et al. (2001) }\end{array}$ \\
\hline 5 & 307 & F103L & Hoffmeyer et al. (2000) \\
\hline 7 & 548 & N183S & Kim et al. (2001) \\
\hline 10 & 1107 & G369P & Hoffmeyer et al. (2000) \\
\hline 11 & 1199 & $\mathrm{~S} 400 \mathrm{~N}$ & $\begin{array}{l}\text { Cascorbi et al. (2001); } \\
\text { Hoffmeyer et al. (2000); } \\
\text { Kim et al. (2001) }\end{array}$ \\
\hline 12 & 1236 & Wobble & $\begin{array}{l}\text { Cascorbi et al. (2001); } \\
\text { Hoffmeyer et al. (2000); } \\
\text { Kim et al. }(2001) ; \\
\text { Kioka et al. (1989) }\end{array}$ \\
\hline 13 & 1474 & $\mathrm{R} 492 \mathrm{C}$ & Kim et al. (2001) \\
\hline 21 & 2650 & Wobble & Kim et al. (2001) \\
\hline 21 & 2677 & $893 \mathrm{~A}, \mathrm{~S}$, or $\mathrm{T}$ & $\begin{array}{l}\text { Cascorbi et al. (2001); } \\
\text { Kim et al. (2001); } \\
\text { Kioka et al. (1989); } \\
\text { Mickley et al. (1998) }\end{array}$ \\
\hline 24 & 2956 & M986V & Tanabe et al. (2001) \\
\hline 24 & 2995 & A999T & Mickley et al. (1998) \\
\hline 26 & 3320 & Q1107P & Cascorbi et al. (2001) \\
\hline 26 & 3396 & Wobble & Hoffmeyer et al. (2000) \\
\hline 26 & 3421 & $\mathrm{~S} 1141 \mathrm{~T}$ & Kim et al. (2001) \\
\hline $26^{\mathrm{a}}$ & 3435 & Wobble & $\begin{array}{l}\text { Hoffmeyer et al. (2000); } \\
\text { Kim et al. (2001); } \\
\text { Kioka et al. (1989) }\end{array}$ \\
\hline 28 & 4030 & - & Tanabe et al. (2001) \\
\hline 28 & 4036 & - & $\begin{array}{l}\text { Kioka et al. (1989); } \\
\text { Tanabe et al. (2001) }\end{array}$ \\
\hline
\end{tabular}

aThe only polymorphism that correlates with changes in drug delivery and disposition

Figure 2, panel b). Comparison between each of these polymorphisms and wild-type $M D R 1$ revealed no modification of cell-surface localization or the level of expression, and no measurable change in the transport function of P-gp with these polymorphisms. We conclude that the common MDR1-coding polymorphisms do not effect P-gp function in a major way, but cannot rule out a more subtle effect on handling individual substrates, some of which are suggested by the studies enumerated below. Our studies suggest that although $M D R 1$ SNPs are frequent and may produce subtle alterations in drug transport, they do not result in a major functional change; this is consistent with the conserved sequence of the gene, and suggests that its function is not dispensable in human populations.

Several examples of altered substrate specificity resulting from polymorphisms of P-gp have been reported in the literature. Although P-gp was initially described as an energy-dependent efflux pump for diverse hydrophobic natural product anticancer drugs such as doxorubicin, vinblastine, and paclitaxel, it has since been shown to transport dozens of different commonly used drugs (see Table 3). Kioka et al. (1989) showed a slight increase in resistance to doxorubicin, but no effect on colchicine or vinblastine 

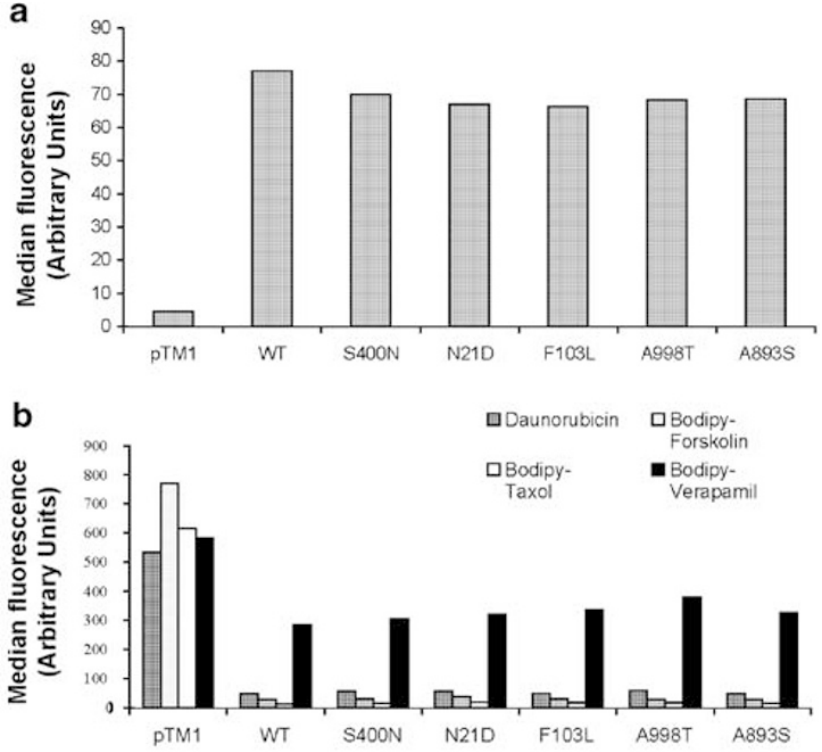

Figure 2 The cell surface expression and transport function of five selected MDR1 polymorphic variants. Panel a: Assessment of cell surface expression of wild-type $M D R 1$ and five $M D R 1$ polymorphic variants using MRK16 - a human P-gp-specific monoclonal antibody. The median fluorescence values obtained with the control monoclonal antibody IgG2ak were subtracted from those obtained with the MRK16. The corrected values are given. Panel b: Drug transport function of wild-type $M D R 1$ and five $M D R 1$ polymorphisms. The drug efflux of Vaccinia virus-infected and transfected HeLa cells was determined by FACS analysis using the following drugs: $0.5 \mu \mathrm{M}$ bodipy-FL-forskolin, $0.5 \mu \mathrm{M}$ bodipy-FLverapamil, $0.1 \mu \mathrm{m}$ bodipy-FL-taxol, and $3 \mu \mathrm{M}$ daunorubicin, as described previously (Kimchi-Sarfaty et al., 2002). HeLa cells were infected/transfected with empty vector (pTM1), wild-type pTM1MDR1, pTM1-MDR1-S400N, pTM1-MDR1-N21D, pTM1MDR1-F103L, pTM1-MDR1-A998T, and pTM1-MDR1-A893S, and were analysed by FACS as described previously (KimchiSarfaty et al., 2002)

Table 3 Selected substrates and modulators of P-glycoprotein

\begin{tabular}{lc}
\hline Substrates & Modulators \\
\hline Vinca alkaloids & Calcium channel blockers \\
Vinblastine & Verapamil \\
Vincristine & Dihydropyridines \\
Anthracyclines & Antiarrhythmics \\
Daunorubicin & Quinine \\
Doxorubicin & Antihypertensives \\
Antibiotics & Reserpine \\
Dactinomycin & Antibiotics \\
Actinomycin D & Cephalosporins \\
Other cytotoxic agents & Immunosuppressants \\
Mitomycin & Cyclosporin A \\
Taxol & Steroid hormones \\
Colchicine & Progesterone \\
Puromycin & HIV protease inhibitors \\
Digoxin & Saquinavir \\
& Alcoholism treatment drug \\
& Disulfiram \\
& Phytochemical \\
\hline
\end{tabular}

resistance in the SNP located on exon 21, position 2677, Ser893 (Kioka et al., 1989). It is important to note that the G185V mutation linked to this SNP in this report has been clearly shown to be responsible for an alteration in drug resistance conferred by P-gp, even when the P-gp carries only the G185V mutation and not the polymorphism. Some enhanced efflux of digoxin, a P-gp substrate (Mayer et al., 1996), by cells expressing the G2677T SNP (Ser893 polymorphism) was described by Kim et al. (2001). Yamauchi et al. (2002) evaluated six patients with neurotoxic events and 11 patients without neurotoxic events, and found that the polymorphism at position 2677 is one of the positive predictors for tacrolimus-induced neurotoxicity (Yamauchi et al., 2002). Tacrolimus is a potent immunosuppressant and P-gp inhibitor, and a possible substrate, which is used to prevent allograft rejection after various kinds of organ transplantations. No correlation was found between $M D R 1$ function (evaluated by Rhodamine 123 efflux assay) in CD34-positive cells from 33 healthy bone marrow donors and the following polymorphisms: intronic position IVS-12 T129C, G2677T, and C3435T (Calado et al., 2002).

\section{Intronic and noncoding polymorphisms in the MDR1 gene}

Very few reports have demonstrated SNPs in the P-gp intronic sequence. The location of polymorphisms in introns $4,5,12,16$, and 17 has been recently reviewed (Kerb et al., 2001b). Goto et al. (2002) observed the most common intronic polymorphism IVS-5 C139T in $63 \%$ of 69 individuals who were recipients of livingdonor liver transplantation. Our own unpublished data based on DNA sequence from 90 individual's DNAs from the Coriell Repository confirmed the location of the intronic polymorphisms reviewed by Kerb et al. $(2001 \mathrm{a}, \mathrm{b})$. Evaluation of the frequency of SNPs in the $M D R 1$ gene in human cancers, and association of this frequency with an acquired multidrug resistance phenotype in those cancers treated with chemotherapy was done by Potocnik et al. (2001). These investigators found mutations and microsatellite instability in both the $M D R 1$ promoter and coding region in colorectal cancer from 50 patients. However, not much other evidence is reported on polymorphisms in the $M D R 1$ promoter region in healthy individuals. Ito et al. (2001) found in one out of 48 healthy Japanese individuals, a change to $\mathrm{G}$ in position -145 (in the promoter region). Another change was reported by the same group at position $-41(\mathrm{~A}-\mathrm{G})$ at a frequency of 0.073 . The number of individuals taken in this study was low, and therefore the frequency might be different in larger samples of this population. The effect of these intronic and promoter polymorphisms in the $M D R 1$ gene is unknown.

\section{The wobble polymorphism 3435 is sometimes correlated with changes in drug delivery or disposition}

The only clearly polymorphic variation of P-gp that contributes to different responses of patients to some MDR1 substrates is an SNP in exon $263435 \mathrm{C}>\mathrm{T}$, which does not result in an amino acid change. There have been several recent reports concerning the appearance of this polymorphism in different ethnic groups. 
Moreover, most of these studies correlated the manifestation of this polymorphism with a change in drug delivery or disposition. The transition from $\mathrm{C}$ to $\mathrm{T}$ at 3435 was associated with decreased intestinal expression of P-gp, and increased digoxin bioavailability; individuals carrying the $\mathrm{CC}$ genotype were found to have high intestinal P-gp levels and low intestinal digoxin uptake, while individuals carrying the TT genotype had low intestinal P-gp levels and high digoxin uptake (Hoffmeyer et al., 2000). In contrast, Sakaeda et al. (2001) found reduced digoxin serum concentration in association with the T allele. Ameyaw et al. (2001) used PCR to characterize the 3435 location in 1280 individuals from 10 different ethnic groups, and found a higher frequency of the $\mathrm{T}$ allele among the African populations, as compared to the Caucasian/Asian populations, indicating that the frequency of the $\mathrm{T}$ allele is significantly influenced by ethnicity. The presence of the $\mathrm{T}$ allele results in decreased P-gp levels in the Caucasian, Chinese, Filipino, Portuguese, and Saudi populations. These authors suggested that a high frequency of the C allele in the African group might explain the high incidence of anticancer drug resistance and more aggressive tumors in individuals of African origin. Hitzl et al. (2001) found higher P-gp activity using Rhodamine 123 in CD56 + cells from 10 individuals carrying the CC genotype, as compared to 11 individuals carrying the TT genotype. Siddiqui et al. (2003) reported an association of the CC genotype with poor response of patients to antiepileptic drugs.

Homozygotes for the $\mathrm{C}$ allele at the 3435 location are associated with lower serum levels of the antihistamine fexofenadine (Allegra ${ }^{\mathrm{TM}}$ ) in a European-American population (Kim et al., 2001). As opposed to the above reviewed studies, von Ahsen et al. (2001) reported no difference in Caucasian renal transplant patients carrying the CC (31 individuals) or CT (54 individuals) or TT (44 individuals) genotypes, receiving cyclosporin A therapy, when measuring the three following parameters: cyclosporin A required for main therapeutic concentrations, dose-adjusted cyclosporin A trough concentrations, and incidence of acute rejection. It remains to be seen whether similar results will be obtained with other drugs or whether this is specific for cyclosporin A, which is likely to be a substrate for transporters other than P-gp.

Other reports found no correlation between the wobble 3435 polymorphism and changes in MDR function. Cascorbi et al. (2001) found 53.9\% heterozygosity for the T allele, and $28.6 \%$ of the 461 unrelated white individuals who were screened (294 men, 167 women) were homozygous $\mathrm{T} / \mathrm{T}$, also without change in function of MDR1. Drescher et al. tested fexofenadine (P-gp substrate) disposition in 10 homozygous CC and 10 homozygous-TT genotypes, German Caucasian, and found no significant differences between the $\mathrm{CC}$ and the TT individuals. However, P-gp function was significantly decreased in the CD56+ cells of the TT compared with the CC individuals (Drescher et al., 2002). Roberts et al. (2002) found that carrying the $T$ allele is a risk factor for the occurrence of nortriptyline- induced portal hypotension in Caucasian patients with a major depression in New Zealand. The genotype TT, at position 3435, was found in eight of 27 Asian patients by Goh et al. (2002) P-gp's role in binding, transport, and distribution of xenobiotics is supported by the study of Siegsmund et al. (2002). These investigators observed in two separate tests (one of 537 healthy individuals and 212 patients with renal epithelial tumors, and the other of 150 healthy individuals and 50 patients with renal epithelial tumors) a correlation between the $\mathrm{T}$ allele and occurrence of the tumor. They showed that $\mathrm{T}$ and TT carriers are at risk for developing nonclear cell renal cell carcinoma (Siegsmund et al., 2002). Another study examined 268 Caucasian men, half of whom were lung cancer patients, and found similar frequencies of genotypes to Hoffmeyer et al. (2000) (Sinues et al., 2003). No association was observed between the $T / T$ genotype and lung cancer.

Our own data (unpublished - Kimchi-Sarfaty et al.) indicate multiple different substitutions at the 3435 site. This variability might reflect the relative insignificance of the specific nucleotide at this intracellular location. Therefore, we would hypothesize that this region would not be very conservative through evolution, and that the specific residue is not likely responsible for the reported linkage to various phenotypes. In conclusion, the 3435 polymorphism (which is not an amino-acid change) has been found in several studies to be associated with a change in the expression of P-gp. Careful study of the number of the individuals in each report indicates that, in some cases, the sample that was evaluated was too small to predict a strong correlation or no correlation between the presence of the 3435 polymorphism and an effect on drug delivery or disposition. Another speculation that might explain the linkage between a change on the DNA (which does not lead to a change in the amino acid) and different expression levels is that the expression of the DNA could be altered even if the protein generated is not. It could be that proteins can bind to one form of the polymorphic RNA and not to the other, or that one form of the RNA is not processed as efficiently as the other because of differences in the folding of the RNA or differences in protein binding. These hypotheses could be tested by comparing levels of RNA that correspond to the different alleles. Another speculation is that this polymorphism may lead to alternative splicing, which would also create a shorter protein compared to the wild-type P-gp. What seems most likely, however, is that in some populations the polymorphic allele at 3435 is linked to another polymorphism which affects P-gp expression or expression of a neighboring gene.

\section{Evidence of specific MDRI haplotypes}

Linkage studies and the resulting haplotypes are powerful tools for screening large populations. The three highly frequent polymorphisms located in exon 12 position 1236, exon 21 position 2677, and exon 26 position 3435 were found in the following studies to have a strong linkage disequilibrium. Kim et al. found a 
linkage between the two synonymous SNPs (C1236T and C3435T) and a nonsynonymous SNP (G2677T, Ala893Ser) in exon 21. It occurred in $62 \%$ of European Americans, and 13\% of African Americans (Kim et al., 2001). Tang et al. (2002) showed high frequencies and strong linkage disequilibrium of these polymorphisms, C1236T, G2677T/A, and C3435T, in three ethnic groups: Chinese, Malays, and Indians. Other researchers found a strong linkage disequilibrium between only two of these three coding polymorphisms: Tanabe et al. (2001) found that in $94 \%$ of DNA samples from 65 Japanese individuals, the $3435 \mathrm{~T}$ allele is linked to Ser or Thr at amino-acid 893 at position 2677 (Tanabe et al., 2001). In the G2677T and C3435T haplotype, which was found in $13.3 \%$ of a random Caucasian population, Johne et al. (2002) found higher plasma levels of digoxin after oral administration (Johne et al., 2002). Significant linkage disequilibrium was also confirmed by Furuno et al. (2002), between the polymorphisms located in positions 2677 and 3435 (Furuno et al., 2002). A study done by Illmer et al. (2002) on 405 acute myeloid leukemia patients detected linkage disequilibrium of these known polymorphisms in exons 21 and 26, and found high probability of relapses in those patients carrying this haplotype (Illmer et al., 2002). Altered absorption and/or disposition of digoxin was reported by Kurata et al. (2002) in 15 healthy individuals carrying the haplotype of double-homozygote TT at positions 2677 and 3435 (Kurata et al., 2002). Similar results were shown by Horinouchi et al. (2002) - a genetic linkage between positions 2677 and 3435 in a Japanese population (Horinouchi et al., 2002). Comparable research done by Moriya et al. (2002) found the same linkage also in Japanese individuals (Moriya et al., 2002). Siddiqui et al. (2003) show evidence of linkage disequilibrium extending from exon 26 to exon 12, and found a haplotype which includes intron 2, exon 12 , exon 21, and exon 26 in high frequency (34.6\%) among 32 core families (Siddiqui et al., 2003).

Another haplotype of the $M D R 1$ gene was reported by Goto et al. (2002). In all, 92\% of 69 recipients of living-donor liver transplantations individuals carrying the TT genotype in exon 12 also carry the TT genotype in the most frequent intronic polymorphism $-6+139$ (Goto et al., 2002).

Studies have also been done to determine whether specific associations exist between polymorphisms of the different cytochrome $P 450$ genes and polymorphisms of the $M D R 1$ gene. An association between excess accumulation of a specific drug due to poor function of the cytochrome $P 450$ enzymes and a polymorphism of $\mathrm{P}$-gp might explain the poor metabolic phenotype of the drug, such as phenytoin. Kerb et al. (2001a,b) reported that the presence of the MDR1 C>T3435 allele in 96 healthy Turkish volunteers is correlated with a high metabolic ratio of p-HPPH and a high level of phenytoin, which is metabolized by cytochrome P450 (Kerb et al., 2001a). Goto et al. (2002) saw a correlation between the $\mathrm{C}$ allele in the polymorphic site 3435 and lower expression of P450 in 69 recipients of living-donor liver transplantation. They have not observed other polymorphisms that correlated with intestinal expression of $M D R 1$ mRNA or the tacrolimus concentration/dose ratio in these individuals (Goto et al., 2002). A recent report suggests that the $249 \mathrm{~A} / \mathrm{A}$ (249I) polymorphism in the $\mathrm{CX}_{3} \mathrm{CR} 1$ chemokine receptor and the $3435 \mathrm{C} / \mathrm{C}$ genotype in the $M D R 1$ gene may be associated with accelerated immunological and virological therapy failure in some of the HIV-infected patients (Brumme et al., 2003). The molecular basis of these associations of polymorphism of P-gp with expression of other genes is unknown, and their significance is at present unclear.

\section{Studies on the structure and function of P-gp: the topological model of human P-gp, and the role of various domains}

P-gp is a typical ABC transporter protein composed of two homologous halves, each containing six transmembrane (TM) domains and an ATP-binding/utilization domain, separated by a flexible linker region (Figure 3 ). It has been shown that deletion of the central core of the linker region of human P-gp results in a protein that is expressed at the cell surface at levels similar to the wildtype protein, but is not functional for either transport or drug-stimulated ATPase activity (Hrycyna et al., 1998). Furthermore, replacement of the deletion with a peptide with a predicted flexible secondary structure was found to be sufficient for restoring the functional properties of the molecule. These data suggest that interaction of the two halves of P-gp is critical for the functioning of the molecule, and that a flexible linker region is sufficient for the proper interaction of the two halves, most likely for the communication between the two ATP sites. The mutational analyses, labeling with the photoaffinity substrate analogues, and crosslinking with the thiol reactive substrate derivatives suggest that the two halves of human P-gp interact to form a single transporter, and that the major drug-binding domains reside in transmembrane domains 4, 5, 6, 10, 11, and 12 (see Ambudkar et al., 1999; Hrycyna, 2001; Loo and Clarke, 2002a).

Biochemical characterization of both human and hamster purified P-gps has determined that both ATP sites are capable of hydrolysing ATP but not simultaneously, that the stoichiometry of ATP hydrolysis is $1 \mathrm{~mol} \mathrm{ATP} / \mathrm{mol}$ of P-gp (Urbatsch et al., 1995a, b; Hrycyna et al., 1999) and that ATP hydrolysis and drug transport are obligatorily linked (Ambudkar et al., 1997). The mutations (depicted as blue filled circles in Figure 3) in mammalian P-gps that affect substrate specificity are found throughout the molecule including the TM regions, soluble intra- and extracellular loops, and the ATP-binding/utilization domains (for a complete list of mutations, see Ambudkar et al., 1999; Hrycyna, 2001). P-gp is glycosylated at three sites (N91, N94, and N99) in the first extracellular loop (wiggly lines in the first extracellular loop in Figure 3) (Schinkel et al., 1993). The glycosylation appears to be required for the proper trafficking of the transporter to the cell surface, but it is not required for the transport function of P-gp (Schinkel et al., 1993; Gribar et al., 2000). P-gp 


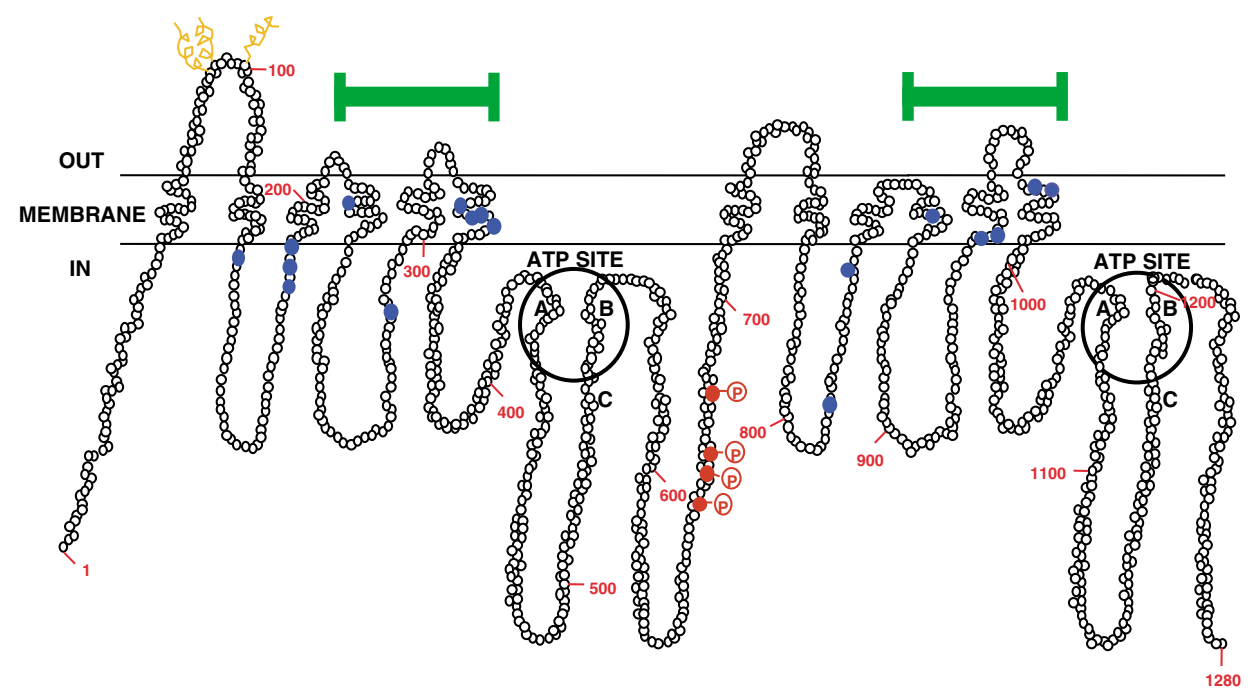

Figure 3 A hypothetical 2-D model of human P-glycoprotein, based on hydropathy analysis of the amino acid sequence and its functional domains. In this diagram, each circle represents an amino acid residue, with blue solid circles showing the positions of mutations that alter the substrate specificity of P-gp (for clarity, not all mutations are shown). The ATP sites are circled, with Walker A, B and the signature or C region indicated as A, B, and C, respectively. The N-linked glycosylation sites (N91, N94, and N99) are indicated by squiggly lines in the first extracellular loop, and the phosphorylation sites (S661, S667, S671, and S683) in the linker region are shown as a red-circled P. The green bars above the TM domains 4-6 and 10-12 show the regions labeled with photoaffinity analogues. Adapted from Gottesman (1988) and Ambudkar et al. (1999)

is also a potent substrate for phosphorylation by protein $\mathrm{A}$ and $\mathrm{C}$ kinases at four serine residues in the linker region (S661, S667, S671, and S683, denoted as red circled P in Figure 3). However, a P-gp mutant lacking all phosphorylation sites exhibits normal transport function, and confers drug resistance to sensitive cells (Germann et al., 1996).

\section{Identifying the sites of interaction between P-gp and its drug substrates}

Drugs belonging to diverse chemical classes and having different targets such as Vinca alkaloids, calcium channel blockers, anthracyclines, antiarrhythmics, epipodophyllotoxins, antihypertensives, antibiotics, immunosuppressants, cytotoxic agents, steroid hormones, and HIV protease inhibitors interact with P-gp (Table 3). Some of these agents may carry a positive charge at physiological $\mathrm{pH}$, but due to their amphipathic nature they can enter cells by passive diffusion (Gottesman and Pastan, 1993). Although modulators (listed in the right panel in Table 3) reverse drug resistance, P-gp efficiently transports a majority of them. Although there have been several generations of P-gp modulators in development, reversing P-gp-mediated MDR in the clinic has met with very limited success (Gottesman et al., 2002; Leonard et al., 2002). The basic strategy to circumvent MDR, however, continues to be the coadministration of an anticancer drug with a chemosensitizer that impairs Pgp function, resulting in enhanced intracellular anticancer drug accumulation.

To design effective modulators of P-gp, it is thus necessary to understand how the transporter interacts with so many structurally diverse chemical agents. The only feature common to P-gp drug substrates appears to be that they are all hydrophobic, with a molecular mass of $300-2000 \mathrm{Da}$ (Ford and Hait, 1990). Anionic compounds are not transported by P-gp. In recent years, Seelig and co-workers have attempted to understand the biophysical characteristics of P-gp substrates, and their theoretical models suggest that it may be a function of the spatial separation of electron donor groups (Seelig, 1998a, b). These authors analysed the structures of a hundred compounds, which had been demonstrated in the literature to interact with P-gp. These compounds were found to possess the following chemical units: (a) Two electron donor groups with a spatial separation of $2.5+0.3 \AA$. (b) Two electron donor groups with a spatial separation of $4.6+0.6 \AA$. (c) Three electron donor groups with a spatial separation of the outer two groups of $4.6+0.6 \mathrm{~A}$. The authors suggest that the occurrence of at least one of these three chemical units in a hydrophobic compound is diagnostic of a P-gp substrate. Moreover, several groups have demonstrated that the number and strength of hydrogen bonds determine the interaction of P-gp and drug substrates (Ecker et al., 1999).

A more direct approach to elucidating the regions of P-gp that interact with drugs is the use of photoaffinity analogues of drug substrates. This has been an active area of research for over a decade, allowing the drugsubstrate-binding regions of P-gp to be extensively mapped. [ $\left.{ }^{125} \mathrm{I}\right]$ iodoarylazidoprazosin (IAAP), an analogue of prazosin (Greenberger, 1993), [ ${ }^{125}$ I] iodomycin, a Bolton-Hunter derivative of daunorubicin (Demmer et al., 1997), $\left[{ }^{3} \mathrm{H}\right]$ azidopine (Bruggemann et al., 1989), 6$O$-[[2-[3-(4-azido-3-[ ${ }^{125}$ I]iodophenyl) propionamido] ethylcarbamyl] forskolin (AIPPF), an analogue of forskolin (Morris et al., 1994), benzophenone analogues of paclitaxel (Taxol) (Wu et al., 1998), analogues of 
cyclosporin A (Demeule et al., 1998), and a $\left[{ }^{3} \mathrm{H}\right]$ benzophenone analogue of stipiamide (Andrus et al., 2000) have yielded valuable information on the direct interaction of P-gp with its substrates.

The sophistication and accuracy of the methods used to identify regions of P-gp interacting with drug substrates vary considerably, and includes the use of antibodies raised against specific regions of P-gp (Bruggemann et al., 1989, 1992; Greenberger, 1993; Morris et al., 1994; Demeule et al., 1998; Wu et al., 1998), HPLC in conjugation with Edman-MS (Demmer et al., 1997, 1999; Isenberg et al., 2001), and more recently MALDI-MS (Borchers et al., 2002; Ecker et al., 2002). The earliest data were obtained by the immunological analysis of P-gp proteolytic fragments after photoaffinity labeling with $\left[{ }^{3} \mathrm{H}\right]$-azidopine, the ${ }^{125} \mathrm{I}$ forskolin derivative, AIPPF, and the ${ }^{125}$ I-prazosin derivative, IAAP (Bruggemann et al., 1989, 1992; Greenberger, 1993; Morris et al., 1994). More recently, iodomycin binding was localized to amino acids 230-312 (the distal part of TM4, the second cytoplasmic loop, and the proximal part of TM5) of hamster P-gp, using Edman sequencing of radiolabeled peptides (Demmer et al., 1997). Using a similar approach, IAAP was found to bind to three sites, amino acids 248-312 (TM4-TM5), 758-800 (beyond TM8), and 1160-1218, which are located within the second cytosolic NBD (Isenberg et al., 2001). We have separated a C-terminal fragment of human P-gp labeled with IAAP, extracted the photoaffinity-labeled C-terminal fragment of P-gp from an Immobilon $\mathrm{C}$ membrane after Western transfer, and subjected it to both complete trypsin digestion and cyanogen bromide digestion to identify the amino-acid residues by matrix-assisted laser desorption ionization mass spectrophotometry (MALDI-MS). We have identified two unique polypeptides of $\mathrm{m} / z$ ratio 1732 and 2350 , that is, approximately $10-12$ and $16-20$ residues, which correspond to a region spanning TM 11 and the sixth extracellular loop (residues 1135-1164; Sauna and Ambudkar, unpublished data). The binding site of cyclosporin A (amino acids 953-1007) has been established by overlapping peptide mapping with different chemical cleavage agents and immunoprecipitation (Demeule et al., 1998). Benzophenone analogues of paclitaxel were used to localize the binding to two sites: amino acids 683-760 (TM7 and TM8) and 985-1088 (half of TM12 and terminating just after the Walker A motif in the second ATP site) (Wu et al., 1998). A comprehensive summary of the localization of drugbinding sites of P-gp from studies with photoaffinity analogues is given in Table 4 . These data suggest that several of the TMs play a role in substrate binding, and that different substrates have different, but perhaps overlapping, binding sites on P-gp.

Information from photoactive drug-substrate analogues has been supplemented by results from site-directed mutagenesis either alone, or used in conjugation with crosslinking agents (Gottesman et al., 1995, 1996; Ambudkar et al., 1999; Hrycyna, 2001). Mutations in P-gp that affect substrate specificity are found to be clustered in TMs 5, 6, 11, and 12, although such mutations are found throughout the molecule (Ambudkar et al., 1999; Hrycyna, 2001). Consistent with the view that drug-substrate binding occurs principally in the transmembrane domains is the finding that the transmembrane domains alone are sufficient for drug binding. A mutant lacking both nucleotide-binding domains and containing only both TM domains could still bind drug substrates (Loo and Clarke, 1999b). Loo and Clarke (1999a) have pioneered the use of cysteinescanning mutagenesis to identify residues that line the drug-substrate binding site(s). In initial studies, the thiol reactive substrate of $\mathrm{P}$-gp dibromobimane was used to screen hundreds of mutants each, with a unique pair of cysteines. These data provided evidence that dibromobimane reacted with cysteines reintroduced in TMs 4, 5, $6,10,11$, and 12 , suggesting that these regions contribute to drug binding (Loo and Clarke, 2001a,b,c). Moreover, by using methanethiosulfonate crosslinkers with spacers of different lengths, it was possible to estimate the drug-binding domain of P-gp (Loo and Clarke, 2001c). The authors propose that the drug-binding domain is funnel shaped and narrow at the cytoplasmic side. The central, putative drug-substrate binding region would have a diameter of $9-25 \AA$, and would be approximately $50 \AA$ at its widest. A model for the drug-binding site emerging from cysteine-scanning mutagenesis and crosslinking experiments has been recently summarized (Loo and Clarke, 2002a). The model indicates a common drug-binding site involving residues from the TM helices $4,5,6,8,9,10,11$, and 12 . However, the authors propose that this common 'pocket' can allow diverse substrates to create their own binding sites, via a substrate-induced fit mechanism where the substrates use a combination of residues from the different TMs. Thus, it is hypothesized that the TMs

Table 4 Drug-binding sites on P-gp identified using photoaffinity analogues

\begin{tabular}{|c|c|c|c|c|}
\hline P-gp source & Pgp-drug substrate & Photoaffinity analogue & Binding site (amino-acid residues) & References \\
\hline Human & Azidopine & Azidopine & $198-440$ and $1028-1270$ & Bruggemann et al. (1992) \\
\hline Mouse & Paclitaxel (taxol) & $\begin{array}{l}3^{\prime} \text { - } p \text {-Benzoyldihydrocinnamoyl } \\
7^{\prime}-p \text {-Benzoyldihydrocinnamoyl }\end{array}$ & $\begin{array}{l}985-1088 \\
683-760\end{array}$ & Wu et al. (1998) \\
\hline Human & Dexniguldipine & Dexniguldipine- $\mathrm{HCl}$ & $468-527$ & Borchers et al. (2002) \\
\hline Hamster & Cyclosporin A & Diazirine-cyclosporin & $953-1007$ & Demeule et al. (1998) \\
\hline Hamster & Daunorubicin & Iodomycin (a Bolton-Hunter derivative) & $230-312$ & Demmer et al. (1997) \\
\hline Hamster & Azidopine & Iodopine (a Bolton-Hunter derivative) & $230-312$ & Demmer et al. (1999) \\
\hline Hamster & Prazosin & Iodoarylazidoprazosin & $248-312,758-800$, and $1160-1218$ & Isenberg et al. (2001) \\
\hline Human & Prazosin & Iodoarylazidoprazosin & 1135-1169 & $\begin{array}{l}\text { Sauna and Ambudkar } \\
\text { (unpublished data) }\end{array}$ \\
\hline
\end{tabular}


that line the binding pocket are quite mobile and the binding of a substrate brings rigidity to the binding site. This is an interesting hypothesis, for which more direct experimental data are required.

\section{The coupling of ATP hydrolysis to substrate transport in $P-g p$}

Most chemotherapeutic agents have a high propensity to partition into the bilayer, and diffuse down a concentration gradient into the cell (Gottesman et al., 1996). P-gp, an ATP-dependent molecular pump, is implicated in expelling these drugs from the cell. The bulk of evidence in the literature corroborates the concept that drug transport by P-gp is coupled to ATP hydrolysis (Senior et al., 1995; Sauna et al., 2001c; Ambudkar et al., 1992), and the ATPase activity of P-gp has been studied in considerable detail (for reviews see Senior et al., 1995; Sauna et al., 2001c). Crude membrane fractions as well as purified P-gp reconstituted into lipid vesicles show a basal level of $\mathrm{Mg}^{2+}$ dependent ATP hydrolysis, which is stimulated by substrates and modulators of P-gp by a factor of up to 10 (Ambudkar et al., 1992; Sarkadi et al., 1992; Sharom et al., 1993, 1995; Urbatsch et al., 1994; Senior et al., 1995; Senior and Gadsby, 1997; Senior, 1998; Kerr et al., 2001). ATP hydrolysis is abolished by chemical modification with $N$-ethylmaleimide (al-Shawi et al., 1994) or mutations in the conserved residues of the Walker A, Walker B or the signature region (Loo and Clarke, 1995a, b; Hrycyna et al., 1999). These data suggest that though both the ATP sites can bind and hydrolyse ATP (Urbatsch et al., 1995a), the interaction of both sites is essential for ATP hydrolysis and drug transport (Hrycyna et al., 1998, 1999). The specific role(s) of the conserved residues in these regions is discussed below. Pgp has a low affinity for nucleotides; the $K_{\mathrm{m}}$ for ATP is in the 0.3-1 mM range (Ambudkar et al., 1992; Urbatsch et al., 1994; Sharom et al., 1995; Kerr et al., 2001), which can present technical difficulties in the kinetic analysis of ATP hydrolysis by P-gp (Urbatsch et al., 1995b). These have been overcome in part, by using orthovanadate (Vi) to generate a stable noncovalent ternary complex in the form of the transition state intermediate Pgp•ADP•Vi (Senior et al., 1995; Sauna et al., 2001c). $\mathrm{Vi}$ is an efficient inhibitor of P-gp ATPase activity because it is similar in size and charge to $P_{i}$, readily increases the coordination sphere to five, and exhibits plasticity in its bond distances (Smith and Rayment, 1996). The P-gp•ADP•Vi species appears to mimic the catalytic transition state with $\mathrm{P}_{\mathrm{i}}$ during ATP hydrolysis by P-gp (Senior and Gadsby, 1997; Sauna et al., 2002). It has been established that it is always a nucleoside diphosphate that is trapped (Urbatsch et al., 1995b; Sankaran et al., 1997; Sauna et al., 2001b). Thus, if ATP (or alternative hydrolysable nucleoside triphosphate) is used to initiate the reaction, at least one turnover of ATP hydrolysis converting ATP to ADP is essential for trapping to occur.

The Vi-induced trapping of P-gp in the P-gp $\left[\alpha^{-32} \mathrm{P}\right] 8$ azidoADP•Vi transition state has also been useful in determining the steps of the catalytic cycle of ATP hydrolysis, where these drugs exert their effect. Compounds that support a higher-fold stimulation of steadystate ATPase activity also demonstrate a higher extent of Vi-induced $\left[\alpha^{-32} \mathrm{P}\right] 8$-azidoADP occlusion in the presence of either $\mathrm{Co}^{2+}$ or $\mathrm{Mg}^{2+}$ into P-gp (Szabo et al., 1998; Kerr et al., 2001), and a very strong linear correlation exists between the extent of $\left[\alpha-{ }^{32} \mathrm{P}\right] 8$-azidoADP trapped into P-gp in the presence of Vi and the steady-state fold stimulation of ATPase activity in the presence of various substrates (Kerr et al., 2001). This correlation suggests that both experimental approaches are measuring the same step in the catalytic cycle of P$\mathrm{gp}$, and that the rate-limiting step in the catalytic cycle is either the release of ADP or $\mathrm{P}_{\mathrm{i}}$. For the Vi-induced trapping of $\left[\alpha{ }^{32} \mathrm{P}\right] 8$-azidoADP, $\mathrm{P}_{\mathrm{i}}$ release is a prerequisite. In addition, $\mathrm{P}_{\mathrm{i}}$ has an extremely low affinity for $\mathrm{P}$ gp, with a $K_{i}$ in the range of $150-200 \mathrm{~mm}$ for ATP hydrolysis. Thus, it is unlikely that the release of $\mathrm{P}_{\mathrm{i}}$ would be the rate-limiting step. Moreover, the rate of the release of 8-azidoADP (or ADP) from the Vitrapped P-gp is not affected by the addition of excess nucleotides such as ATP, ADP, or AMPPNP. Finally, there is an inverse relationship between ADP release from the $\mathrm{P}$-gp $\bullet \mathrm{MgADP} \bullet \mathrm{Vi}$ complex and the recovery of the substrate binding to the transporter, following formation of the transition state. Though it is not clear how drugs affect the rate of release of ADP, these results

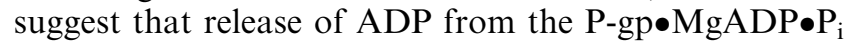
transition state is the rate-limiting step in the catalytic cycle of P-gp (Kerr et al., 2001; Sauna et al., 2001c).

\section{Comparison of the activation energies required for various steps in ATP hydrolysis by P-gp}

Recently, we demonstrated (Sauna et al., 2001a, b) that it is possible to initiate Vi-induced trapping under hydrolysis or nonhydrolysis conditions by using either $\left[\alpha-{ }^{32} \mathrm{P}\right] 8$ azidoATP or $\left[\alpha-{ }^{32} \mathrm{P}\right] 8$-azidoADP. Trapping by either route showed similar kinetics, similar distribution of trapped 8-azidoADP between the $\mathrm{N}$ - and $\mathrm{C}$-terminal halves of P-gp, and the same requirement for divalent cations. We therefore determined the activation energies required for various steps during ATP hydrolysis, in order to see whether we could distinguish the transitionstate intermediate formed in the presence and absence of ATP hydrolysis. The activation energy calculated from the slope of the Arrhenius plots (Sauna et al., 2001b) for basal and verapamil-stimulated ATP (or 8-azidoATP) hydrolysis is in the range of $100-115 \mathrm{~kJ} / \mathrm{mol}$. This activation energy is much higher than that reported for P- and F-type ATPases such as $\mathrm{Na}^{+}-\mathrm{K}^{+}$-ATPase and $\mathrm{F}_{0} \mathrm{~F}_{1}$-ATPase $(50-60 \mathrm{~kJ} / \mathrm{mol})$. The reason for the requirement of higher activation energy for ATP hydrolysis by P-gp is not clear at present. Similar measurements for ATP hydrolysis by other ABC transporters have not yet been carried out. The activation energy for the Vi-induced trapping of $\left[\alpha-{ }^{32} \mathrm{P}\right] 8$ azidoADP under hydrolysis conditions is $62 \mathrm{~kJ} / \mathrm{mol}$, or about half that for verapamil-stimulated ATP hydrolysis (see Figure 4). On the other hand, the trapping of 
$\left[\alpha-{ }^{32} \mathrm{P}\right] 8$-azidoADP in the presence of Vi under nonhydrolysis conditions requires $152 \mathrm{~kJ} / \mathrm{mol}$ activation energy, which is about $\sim 2.5$-fold higher compared to that required to trap nucleotide under hydrolysis conditions, and is 1.5 times higher than that required for verapamilstimulated hydrolysis of ATP or 8-azidoATP (which represents the complete catalytic cycle). These data indicate that the formation of the transition-state intermediate under nonhydrolysis conditions is energetically a highly unfavorable reaction.

\section{Substrate-stimulated ATP hydrolysis is a vectorial process}

The generation of a transition-state intermediate of P-gp under nonhydrolysis conditions, although energetically unfavorable, raised the question as to whether, in the presence of a sufficiently high substrate gradient, ATP can be generated from ADP and $\mathrm{P}_{\mathrm{i}}$. With some of the Ptype ATPases, reversal of the ion concentration gradient under in vitro conditions has been shown to drive synthesis of ATP from ADP (Yamada and Ikemoto, 1980; Repke, 1982). When P-gp is pretreated with substrate or modulator, the Vi-induced trapping of $\left[\alpha{ }^{32} \mathrm{P}\right] 8$-azidoADP under nonhydrolysis conditions is strongly inhibited. In the presence of substrate or modulator under nonhydrolysis conditions, the affinity for nucleoside diphosphate (ADP or $\left[\alpha-{ }^{32} \mathrm{P}\right] 8$-azidoADP) is drastically decreased (Sauna et al., 2001a). These results indicate that substrates shift the equilibrium, driving the reaction in the forward direction, which results in the dissociation of $\mathrm{P}_{\mathrm{i}}$ and ADP from the $\mathrm{P}$ gp $\bullet A D P \bullet P_{i}$ catalytic state intermediate following ATP hydrolysis, rather than the formation of the transitionstate intermediate when ADP and $\mathrm{P}_{\mathrm{i}}$ are provided under nonhydrolysis conditions. Taken together, these results suggest that the combination of (i) the requirement for an intrinsic large energy barrier, and (ii) the modulation

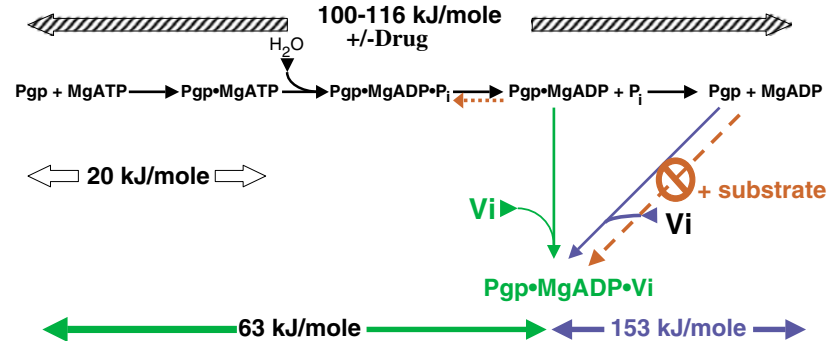

Figure 4 Activation energies required for various steps in the catalytic cycle of P-gp, and the effect of substrates on Vi-induced trapping of ADP under nonhydrolysis conditions. The arrows as indicated represent the values $(\mathrm{kJ} / \mathrm{mol})$ for the activation energies of nucleotide binding (empty arrow), Vi-induced trapping of $\left[\alpha-{ }^{32} \mathrm{P}\right] 8$-azidoADP through hydrolysis of $\left[\alpha-{ }^{32} \mathrm{P}\right] 8$-azidoATP (filled green), steady-state hydrolysis of ATP or 8-azidoATP in the presence or absence of verapamil (hatched black arrow), and $\mathrm{Vi}$ induced $\left[\alpha-{ }^{32} \mathrm{P}\right] 8$-azidoADP trapping in the absence of hydrolysis (blue arrow). However, preincubation of $\mathrm{P}$-gp with substrate (verapamil) blocks the $\mathrm{Vi}$-induced $\left[\alpha-{ }^{32} \mathrm{P}\right] 8$-azidoADP trapping in the absence of hydrolysis (red arrow with $\otimes$ ); as a result, step 3 is not reversible (indicated by broken red backward arrow). Adapted from Sauna et al. (2001a, b) by drug substrates does not permit the backward reaction either in the absence or presence of drug substrates. The mechanism by which drug substrates block the formation of the transition state in the absence of ATP hydrolysis is not understood at present. We have speculated that the conserved dodecapeptide linker region, also known as the $\mathrm{ABC}$ signature motif, which is implicated in the signal transduction from substratebinding domains to the ATP sites, may play a role in this phenomenon. The failure to obtain a Vi-induced ADPtrapped transition-state intermediate of bacterial maltose permease in the presence of maltose and maltose-binding protein under nonhydrolysis conditions (Sharma and Davidson, 2000) lends support to the concept of substrate-mediated modulation of ATP hydrolysis, which may be common to other ABC transporters. This is in contrast to P-type ATPases such as the $\mathrm{Ca}^{2+}$ ATPase of sarcoplasmic reticulum and the $\mathrm{Na}^{+}, \mathrm{K}^{+}$ ATPase, where reversal of ion-concentration gradient has been shown at least in vitro to drive synthesis of ATP from ADP (Yamada and Ikemoto, 1980; Repke, 1982).

\section{Role of the conserved Walker B glutamate residues E556 and E1201 in ATP hydrolysis by P-gp}

In addition to the biochemical studies outlined above, the recent spate of crystal structures of the ATP sites of several ABC transporters (Hung et al., 1998; Diederichs et al., 2000; Chang and Roth, 2001; Gaudet and Wiley, 2001; Karpowich et al., 2001; Bohm et al., 2002; Locher et al., 2002) has considerably extended our knowledge of the nucleotide-binding pocket and the mechanism by which ATP is hydrolysed. These structures indicate critical roles for two residues in the Walker $\mathrm{B}$ region of the NBD, which are conserved in a majority of $\mathrm{ABC}$ transport proteins. These are residues homologous to the pairs D555/D1200 and E556/E1201 in human P-gp. Site-directed mutagenesis in P-gp (Urbatsch et al., 1998; Hrycyna et al., 1999) has confirmed that the D555/ D1200 pair is involved in the coordination of $\mathrm{Mg}^{2+}$. The residues that correspond to the pairs E556/E1201 in the Walker B region and Q475/1118 in the Q loop of human P-gp ATP sites, on the other hand, are postulated to form hydrogen bonds with water molecules that interact with the $\gamma$-phosphate. Hydrolysis of ATP occurs via the attack of a water molecule on the $\gamma$-phosphate (Sleep et al., 1980; Dale and Hackney, 1987), and it is often the side chain of an amino acid that activates the attacking water molecule by deprotonation. Biochemical evidence suggests that these residues (E556, E1201, Q475, or Q1118) are unlikely to play a role in the hydrolysis of the bond between the $\gamma$-P and the $\beta$-P of ATP. Senior and co-workers have demonstrated in mouse Mdr3 that the residues equivalent to Q475 and Q1118 of human Pgp are involved neither in the activation of the attacking water for ATP hydrolysis, nor in the coordination of the essential $\mathrm{Mg}^{2+}$ cofactor in $\mathrm{Mg}^{2+}$ nucleotide (Urbatsch et al., 2000a). Similarly, the mouse Mdr3 mutants E552Q and E1197Q show normal levels of Vi-dependent $\left[\alpha-{ }^{32} \mathrm{P}\right] 8$-azidoADP trapping (Urbatsch et al., 2000b), suggesting that they are capable of ATP hydrolysis. 
Furthermore, the equivalent mutations in human P-gp, E556Q, E556A, E1201Q, E1201A, and the double mutants E556Q/E1201Q and E556A/E1201A, all allow for normal levels of $\mathrm{Vi}$-dependent $\left[\alpha{ }^{32} \mathrm{P}\right] 8$-azidoADP trapping, and the trapped nucleotide has been demonstrated to be $\left[\alpha-{ }^{32} \mathrm{P}\right] 8$-azidoADP (Sauna et al., 2002). Thus, the substitutions of the residues E556 and E1201 with Q or A in human P-gp do not block hydrolysis of ATP per se. Interestingly, the double mutants E556Q/ E1201Q and E556A/E1201A show trapping of $\left[\alpha{ }^{32} \mathrm{P}\right] 8-$ azidoADP even in the absence of Vi. This transition state obtained in the absence of Vi has been extensively characterized, and it has been demonstrated that it is comparable to the Vi-transition state of wild-type P-gp (Sauna et al., 2002). These double mutants of P-gps (E556Q/E1201Q and E556A/E1201A) thus provide an independent validation that the Vi-trapped transition state of P-gp is indeed a 'true' transition state, and they provide an interesting system where one can obtain the transition state of P-gp in the absence of agents such as $\mathrm{Vi}$ or beryllium fluoride. Thus, the identification of mutations which result in trapping of P-gp in a transition state validates the central premises of the use of Vi to study the catalytic cycle of P-gp: that the P$\mathrm{gp} \bullet \mathrm{ADP} \bullet \mathrm{Vi}$ and $\mathrm{P}-\mathrm{gp} \bullet \mathrm{ADP} \bullet \mathrm{P}_{\mathrm{i}}$ are similar, and that the transition state $\mathrm{P}$-gp $\bullet A D P \bullet P_{i}$, represents an intermediate state in the ATP hydrolysis pathway.

The speculations vis-à-vis the 'catalytic carboxylate' in $\mathrm{ABC}$ transporters are reminiscent of the situation in the myosin molecule, where it was initially postulated that a catalytic carboxylate activated the attacking water molecule. However, the crystal structures demonstrated that there was no such group within $5.5 \AA$ of the $\gamma$ phosphate (Fisher et al., 1995). It is now widely accepted that the nucleotide itself is the base, and water transfers its proton directly to the $\gamma$-phosphate (for a review, see Rayment, 1996). One would argue for a similar mechanism in the ATP site of P-gp and other ABC transport proteins. A detailed analysis of conservative and nonconservative substitutions of glutamates at positions 556 and 1201 in human P-gp suggests that these residues are critical for the second ATP hydrolysis event (Sauna et al., 2002), which we have previously demonstrated to be associated with resetting the P-gp molecule following the transport of drug (Sauna and Ambudkar, 2000, 2001). Thus, we have postulated (Sauna et al., 2002) that these residues are likely to be a part of the switch region of $\mathrm{ABC}$ transport proteins deemed to be involved in transmission of interdomain signals from the substrate-binding sites via the D-loop and the $\mathrm{ABC}$ signature region (Bohm et al., 2002; Locher et al., 2002).

\section{The catalytic cycle of ATP hydrolysis by P-gp}

Studies such as those described above provide important details about ATP hydrolysis by P-gp. However, the eventual goal is to understand the mechanism of drug transport by P-gp, that is, how ATP hydrolysis is coupled to drug efflux. The first model for the catalytic scheme of ATP hydrolysis by P-gp was postulated by Senior and co- workers (Senior et al., 1995; Senior and Gadsby, 1997; Senior, 1998). The essential feature of this paradigm was the alternating hydrolysis of ATP at the two ATP-binding sites. It was proposed that the nucleotide first binds to one of the two sites, but cannot be hydrolysed. When another nucleotide binds to the second site, it promotes hydrolysis at the first site, which in turn powers substrate transport. In the next cycle, hydrolysis occurs at the second ATP site. This model is based on the evidence that Vi trapping of the nucleotide at either catalytic site arrests ATP hydrolysis at both sites, and that mutations or chemical modifications that inactivate one catalytic site also prevent catalysis at the other site (Loo and Clarke, 1995a, b; Senior and Bhagat, 1998; Hrycyna et al., 1999). This catalytic scheme was an extremely useful conceptual tool to frame questions and design experiments to understand the mechanistic details vis-à-vis the catalytic cycle, and to address the question of how ATP hydrolysis is coupled to drug-substrate transport.

P-gp exhibits low affinity for ATP compared to, for example, myosin or the mitochondrial $\mathrm{F}_{1} \mathrm{~F}_{0}$-ATP synthase (Senior, 1998; Sauna et al., 2001b). Additionally, in $\mathrm{P}$-gp, no covalent phosphorylated $(\mathrm{E} \sim \mathrm{P})$ intermediate has been demonstrated, as is known to occur for the P-type ATPases (Lelong et al., 1994; Senior, 1998). These facts led Senior and coworkers to hypothesize that, during ATP hydrolysis, a state of high chemical potential is generated, and that the relaxation of such a state powers the extrusion of the drug substrate (Senior et al., 1995; Senior and Gadsby, 1997; Senior, 1998). Recent work from our laboratory experimentally demonstrated a large conformational change accompanying ATP hydrolysis. We showed that the long-lived P-gp $\bullet$-azidoADP•Vi transition state complex that is generated immediately following ATP hydrolysis, exhibits a drastic decrease in the affinity for the substrate analogue ${ }^{125}$ I]IAAP (Ramachandra et al., 1998; Sauna and Ambudkar, 2000, 2001), and also for the nucleotide $\left[\alpha-{ }^{32} \mathrm{P}\right] 8$-azidoATP (Sauna and Ambudkar, 2001). Thus, conformational changes that follow ATP hydrolysis reduce the affinity of both substrate and nucleotide for P-gp, and the extent of decrease in the affinity of the nucleotide $\left[\alpha-{ }^{32} \mathrm{P}\right] 8$-azidoATP is comparable to that for the drug-substrate $\left[{ }^{125}\right.$ I]IAAP.

There has been a general consensus in the literature that there is extensive communication between the substrate-binding sites and NBDs of P-gp (reviewed in Sauna et al., 2001c). However, few studies have experimentally addressed the link between ATP hydrolysis and substrate-binding sites. We have recently exploited the reduced affinity of substrate for P-gp in the Vi-trapped conformation (Sauna and Ambudkar, 2000, 2001; Sauna et al., 2001b) to investigate the interactions between the nucleotide and substratebinding sites, and their energetic requirements to elucidate the catalytic cycle of P-gp, in considerable detail. The essential features of the cycle are illustrated in Figure 5. The drug and ATP first bind to P-gp (Step I), there being no energetic requirement for the drug to bind. We base this conclusion on the observation that binding of the photoaffinity analogue of the P-gp drug- 
substrate prazosin [125I]IAAP is not affected by nucleotides (Sauna and Ambudkar, 2000). A key finding that allowed interactions between the drug substrate and ATP sites to be studied was that following ATP hydrolysis in the presence of $\mathrm{Vi}$, the transition-state intermediate $\mathrm{P}$-gp $\bullet \mathrm{ADP} \bullet \mathrm{Vi}$ showed a drastically reduced affinity for a substrate for P-gp, [ $\left.{ }^{125} \mathrm{I}\right] \mathrm{IAAP}$ (Ramachandra et al., 1998; Sauna and Ambudkar, 2000, 2001). Based on these data, it appears that ATP hydrolysis is a prerequisite for the conformational changes that result in reduced affinity for the substrate. Similarly, Loo and Clarke, using a thiol-reactive substrate, Tris-(2-maleimidoethyl) amine (TMEA), and a series of cysteineless mutants of P-gp have demonstrated rotations in the TM helices TM6 and TM12 (implicated in drug-substrate binding) following ATP hydrolysis, which are not induced by ATP binding per se (Loo and Clarke, 2001a, b). Higgins and co-workers, on the other hand, studying the binding of $\left[{ }^{3} \mathrm{H}\right]$-vinblastine, suggest that binding of ATP even in the absence of hydrolysis is sufficient to induce reduced binding of $\left[{ }^{3} \mathrm{H}\right]-$ vinblastine (Rosenberg et al., 2001). Besides the reduced affinity for substrate that follows ATP hydrolysis (step II), we have demonstrated that there is a corresponding decrease in the affinity of nucleotide (Sauna and Ambudkar, 2001) for P-gp.

Following hydrolysis, Pi and, presumably, the drug are released because of the low affinity for the drug (step III). The subsequent release of ADP (step IV) occurs spontaneously, and is not influenced by the presence of nucleotides. The dissociation of ADP is accompanied by a conformational change that allows nucleotide binding, but substrate binding continues to be reduced (Sauna and Ambudkar, 2001). A second ATP hydrolysis event is then initiated by the binding of a molecule of ATP (step V). The hydrolysis of this ATP (step VI) is kinetically indistinguishable from the first (Sauna and Ambudkar, 2001), at which point the substrate binding is still not regained. This event too can be captured as an intermediate using Vi to trap the nucleotide (see Sauna and Ambudkar, 2001) for experimental strategy. The subsequent release of Pi (step VII) and then ADP (step VIII) completes one catalytic cycle, bringing the P-gp molecule back to the original state, where it can bind both substrate and nucleotide to initiate the next cycle.

This model suggests two unique and distinct roles for ATP hydrolysis in a single turnover of the catalytic cycle of P-gp. Not only is energy utilized in the transport of substrate, but also there is a clear need for ATP hydrolysis in effecting conformational changes in the molecule, which make it available for the next catalytic cycle (Sauna and Ambudkar, 2000). This is consistent with the fact that the hydrolysis of at least two molecules of ATP is required for the transport of every molecule of substrate (Ambudkar et al., 1997; Shapiro and Ling, 1998) by P-gp and several other ABC transporters (Mimmack et al., 1989; Liu et al., 1997). We have also determined that the two hydrolysis events in a single catalytic cycle are kinetically identical, and differ only with respect to the status of the molecule vis-à-vis substrate binding, suggesting that ATP does not show

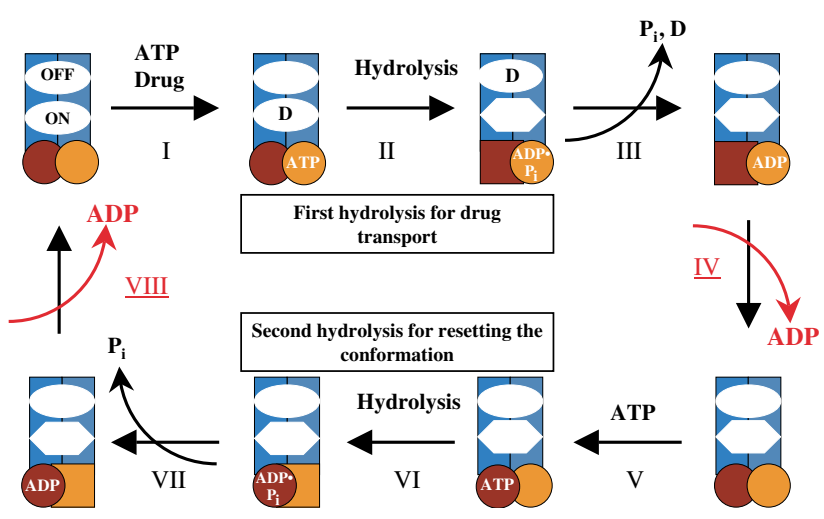

Figure 5 A proposed scheme for the catalytic cycle of P-gp. This scheme is based on the data presented in Sauna and Ambudkar (2000, 2001), and Sauna et al. (2002). The ellipses represent the substrate-binding sites: the 'ON' (high affinity) and the 'OFF' (low affinity) site. The hexagon depicts the 'ON' site with reduced affinity for the drug. The green circles represent the ATP sites, and the empty square portrays the ATP site with reduced affinity for nucleotide. Step I: substrate binds to the high-affinity 'ON' site of P-gp, and ATP binds to either of the two ATP sites. Step II: ATP is hydrolysed and the drug is moved to the lower-affinity 'OFF' site. Step III: $\mathrm{P}_{\mathrm{i}}$ is released and the drug extruded from $\mathrm{P}$-gp at this step. Step IV: the ADP and Vi dissociate from the complex, the ATP sites revert to the 'high-affinity' state, but affinity for drug substrate continues to be low. Step V: following disassociation of the ADP in step IV, an additional molecule of ATP binds to the alternate ATP site. Step VI: ATP is hydrolysed. Step VII: $P_{i}$ is released. Step VIII: the disassociation of ADP allows the conformation of P-gp to be restored to its original state (step I), to initiate the next cycle. The ADP release at steps IV and VIII (underlined) appears to be rate limiting in the catalytic cycle. ATP hydrolysis is shown as being initiated in the C-terminal ATP site; our data suggest that the site of initiation of ATP hydrolysis may be random, but the two sites operate alternately (Sauna et al., 2002)

preferential affinity to either ATP site, and that the sites are recruited randomly for hydrolysis (Sauna and Ambudkar, 2001).

The studies described in the section 'The role of the conserved Walker B glutamate residues E556 and E1201 in ATP hydrolysis by P-gp', originally designed to understand the role of the putative catalytic carboxylates in P-gp (Urbatsch et al., 2000b; Sauna et al., 2002), also provide evidence for two ATP hydrolysis events during a single catalytic cycle of P-gp. Double mutants, where the conserved glutamates in both the Nand C-ATP sites are replaced by either Q or A, are unable to release ADP, that is, the catalytic cycle is possibly terminated at step IV (Figure 5). The single mutants (E556Q, E556A, E1201Q, and E1201A) on the other hand show normal release of ADP, and can bind ATP during next step, but are unable to hydrolyse it. Thus, in these mutants the catalytic cycle is blocked at step VI (Figure 5). Though the single and the double mutants are blocked at different steps, these mutants are unable to execute the second ATP hydrolysis event, and the phenotype for these mutants is that they show loss of steady-state ATPase and drug-transport activities (Urbatsch et al., 2000b; Sauna et al., 2002). These studies thus provide an independent line of evidence for the necessity of two ATP hydrolysis events during a single catalytic cycle of P-gp. 


\section{Perspectives}

This review highlights the role of $\mathrm{P}$-gp in human cancer and in drug pharmacokinetics, and demonstrates that an understanding of its mechanism of action has implications both for manipulating its function and for gaining insight into other members of the large family of $\mathrm{ABC}$ transporters. There are, however, many limitations to our current knowledge. First priority must be given to answering several important questions:

(1) What is the high-resolution, atomic level structure of P-gp both with and without substrates and inhibitors bound? This information will be essential for building models that explain the broad range of substrate interactions with the transporter, and for a detailed understanding of the allosteric changes that occur during the hydrolysis of ATP. With this information, it will be possible to design high-affinity, specific inhibitors, and to generalize the mechanism of action to include (or exclude) other members of the ABC transporter family. The structure of a bacterial homolog of P-gp, MsbA, at moderate (4.5 ̊) resolution has been reported (Chang and Roth, 2001). Further studies are needed to improve the resolution and validate this structure, before its relevance to the mechanism of action of P-gp can be determined.

(2) What is the relevance of expression of P-gp and other ABC transporters in human cancers? It will be necessary first to catalog all of the human ABC transporters with respect to their expression and function in human tissues and cancers. This can be done using the existing microarray expression technologies, proteomics, and cellular localization approaches, combined with functional assays of drug transport. Once this is accomplished, clinical trials that examine the expression and function of candidate transporters will need to be done to establish the relevance of their expression to drug resistance, followed by the use of specific inhibitors to establish their importance in drug resistance. A better understanding of the factors that regulate expression of $\mathrm{ABC}$ transporters, and their possible induction by cytotoxic drugs, is also needed to design clinically relevant strategies.

\section{References}

Allikmets R, Schriml LM, Hutchinson A, Romano-Spica V and Dean M. (1998). Cancer Res., 58, 5337-5339.

Al-Shawi MK, Urbatsch IL and Senior AE. (1994). J. Biol. Chem., 269, 8986-8992.

Ambudkar SV, Cardarelli CO, Pashinsky I and Stein WD. (1997). J. Biol. Chem., 272, 21160-21166.

Ambudkar SV, Dey S, Hrycyna CA, Ramachandra M, Pastan I and Gottesman MM. (1999). Annu. Rev. Pharmacol. Toxicol., 39, 361-398.

Ambudkar SV, Lelong IH, Zhang J, Cardarelli CO, Gottesman MM and Pastan I. (1992). Proc. Natl. Acad. Sci. USA, 89, 8472-8476.

Ameyaw MM, Regateiro F, Li T, Liu X, Tariq M, Mobarek A, Thornton N, Folayan GO, Githang'a J, Indalo A, Ofori-
(3) What role do the ABC transporters, especially P-gp, play in determining the pharmacokinetics of anticancer drugs and other commonly used pharmaceuticals? Preliminary evidence suggests that knowledge of the level of expression, and perhaps function, of $\mathrm{ABC}$ transporters will allow prediction of individual variability in response to specific drugs, which are substrates for these transporters. The relative role of $\mathrm{ABC}$ transporters and other drug metabolism (e.g., the cytochrome $P 450$ system and conjugating enzymes) will have to be assessed.

(4) Can our knowledge of ABC transporters be used in any other way to understand normal human physiology and human disease? Many of the ABC transporters have been shown to be essential, based either on knockout mouse models or specific human diseases in which $\mathrm{ABC}$ transporter function is disabled (Gottesman and Ambudkar, 2001). Although beyond the scope of this review, it should be possible to design specific gene therapies, or drug therapies, which correct defects resulting from the failure of function of $\mathrm{ABC}$ transporters. In addition, we have suggested that some of the ABC transporters, such as P-gp, might prove useful as selectable markers for gene therapy, or to protect bone marrow during cancer therapy (Gottesman et al., 2002).

In summary, much is known about P-gp as a model member of the family of $\mathrm{ABC}$ transporters, but much work remains to be done to characterize this unusually large family of proteins, and to use this information to help ameliorate human disease.

\section{Abbreviations}

ABC, ATP-binding cassette; IAAP, iodoarylazidoprazosin; MDR, multidrug resistance; P-gp, P-glycoprotein; TM, transmembrane; $\mathrm{Vi}$, orthovanadate.

\section{Acknowledgements}

We thank John Gribar for constructing Figure 1 and George Leiman and Joyce Sharrar for help with preparation of the manuscript.

Adjei D, Price-Evans DA and McLeod HL. (2001). Pharmacogenetics, 11, 217-221.

Andrus MB, Turner TM, Sauna ZE and Ambudkar SV. (2000). Bioorg. Med. Chem. Lett., 10, 2275-2278.

Belinsky MG and Kruh GD. (1999). Br. J. Cancer, 80, 1342-1349.

Bergen AAB, Plomp AS, Schuurman EJ, Terry S, Breuning M, Dauwerse H, Swart J, Kool M, van Soest S, Baas F, ten Brink JB and de Jong P. (2000). Nat. Genet., 25, 228-231.

Bohm A, Diez J, Diederichs K, Welte W and Boos W. (2002). J. Biol. Chem., 277, 3708-3718.

Borchers C, Boer R, Klemm K, Figala V, Denzinger T, Ulrich WR, Haas S, Ise W, Gekeler V and Przybylski M. (2002). Mol. Pharmacol., 61, 1366-1376. 
Borst P and Elferink RO. (2002). Annu. Rev. Biochem., 71, 537-592.

Borst P, Evers R, Kool M and Wijnholds J. (1999). Biochim. Biophys. Acta, 1461, 347-357.

Borst P, Evers R, Kool M and Wijnholds J. (2000). J. Natl. Cancer Inst., 92, 1295-1302.

Brangi M, Litman T, Ciotti M, Nishiyama K, Kohlhagen G, Takimoto C, Robey R, Pommier Y, Fojo T and Bates SE. (1999). Cancer Res., 59, 5938-5946.

Brinkmann U, Roots I and Eichelbaum M. (2001). Drug Discov. Today, 6, 835-839.

Bruggemann EP, Currier SJ, Gottesman MM and Pastan I. (1992). J. Biol. Chem., 267, 21020-21026.

Bruggemann EP, Germann UA, Gottesman MM and Pastan I. (1989). J. Biol. Chem., 264, 15483-15488.

Brumme ZL, Dong WW, Chan KJ, Hogg RS, Montaner JS, O'Shaughnessy MV and Harrigan PR. (2003). AIDS, 17, 201-208.

Bunting KD. (2002). Stem Cells, 20, 11-20.

Calado RT, Falcao RP, Garcia AB, Gabellini SM, Zago MA and Franco RF. (2002). Haematologica, 87, 564-568.

Cascorbi I, Gerloff T, Johne A, Meisel C, Hoffmeyer S, Schwab M, Schaeffeler E, Eichelbaum M, Brinkmann U and Roots I. (2001). Clin. Pharmacol. Ther., 69, 169-174.

Chang G and Roth CB. (2001). Science, 293, 1793-1800.

Chen CJ, Chin JE, Ueda K, Clark DP, Pastan I, Gottesman MM and Roninson IB. (1986). Cell, 47, 381-389.

Chen CJ, Clark D, Ueda K, Pastan I, Gottesman MM and Roninson IB. (1990). J. Biol. Chem., 265, 506-514.

Chen ZS, Lee K and Kruh GD. (2001). J. Biol. Chem., 276, 33747-33754.

Chen ZS, Hopper-Borge E, Belinsky MG, Shchaveleva I, Kotova E and Kruh GD. (2003). Mol. Pharmacol., 63, 351-358.

Childs S, Yeh RL, Hui D and Ling V. (1998). Cancer Res., 58, 4160-4167.

Cole SP, Bhardwaj G, Gerlach JH, Mackie JE, Grant CE, Almquist KC, Stewart AJ, Kurz EU, Duncan AM and Deeley RG. (1992). Science, 258, 1650-1654.

Dale MP and Hackney DD. (1987). Biochemistry, 26, 8365-8372.

de Vree JM, Jacquemin E, Sturm E, Cresteil D, Bosma PJ, Aten J, Deleuze JF, Desrochers M, Burdelski M, Bernard O, Oude Elferink RP and Hadchouel M. (1998). Proc. Natl. Acad. Sci. USA, 95, 282-287.

Dean M, Hamon Y and Chimini G. (2001). J. Lipid Res., 42, $1007-1017$

Decleves X, Chevillard S, Charpentier C, Vielh P and Laplanche JL. (2000). Hum. Mutat., 15, 486.

Demeule M, Laplante A, Murphy GF, Wenger RM and Beliveau R. (1998). Biochemistry, 37, 18110-18118.

Demmer A, Andreae S, Thole H and Tummler B. (1999). Eur. J. Biochem., 264, 800-805.

Demmer A, Thole $\mathrm{H}$, Kubesch $\mathrm{P}$, Brandt $\mathrm{T}$, Raida M, Fislage R and Tummler B. (1997). J. Biol. Chem., 272, 20913-20919.

Diederichs K, Diez J, Greller G, Muller C, Breed J, Schnell C, Vonrhein C, Boos W and Welte W. (2000). EMBO J., 19, 5951-5961.

Doyle LA, Yang W, Abruzzo LV, Krogmann T, Gao Y, Rishi AK and Ross DD. (1998). Proc. Natl. Acad. Sci. USA, 95, $15665-15670$

Drescher S, Schaeffeler E, Hitzl M, Hofmann U, Schwab M, Brinkmann U, Eichelbaum M and Fromm MF. (2002). Br. J. Clin. Pharmacol., 53, 526-534.

Ecker G, Huber M, Schmid D and Chiba P. (1999). Mol. Pharmacol., 56, 791-796.
Ecker GF, Csaszar E, Kopp S, Plagens B, Holzer W, Ernst W and Chiba P. (2002). Mol. Pharmacol., 61, 637-648.

Ejendal KFK and Hrycyna CA. (2002). Curr. Protein Pept. Sci., 3, 503-511.

Evans WE and McLeod HL. (2003). N. Engl. J. Med., 348, 538-549.

Fisher AJ, Smith CA, Thoden JB, Smith R, Sutoh K, Holden HM and Rayment I. (1995). Biochemistry, 34, 8960-8972.

Fojo AT, Shen DW, Mickley LA, Pastan I and Gottesman MM. (1987). J. Clin. Oncol., 5, 1922-1927.

Ford JM and Hait WN. (1990). Pharmacol. Rev., 42, 155-199.

Furuno T, Landi MT, Ceroni M, Caporaso N, Bernucci I, Nappi G, Martignoni E, Schaeffeler E, Eichelbaum M, Schwab M and Zanger UM. (2002). Pharmacogenetics, 12, 529-534.

Gaudet R and Wiley DC. (2001). EMBO J., 20, 4964-4972.

Gerloff T, Stieger B, Hagenbuch B, Madon J, Landmann L, Roth J, Hofmann AF and Meier PJ. (1998). J. Biol. Chem., 273, 10046-10050.

Germann UA, Chambers TC, Ambudkar SV, Licht T, Cardarelli CO, Pastan I and Gottesman MM. (1996). J. Biol. Chem., 271, 1708-1716.

Goh BC, Lee SC, Wang LZ, Fan L, Guo JY, Lamba J, Schuetz E, Lim R, Lim HL, Ong AB and Lee HS. (2002). J. Clin. Oncol., 20, 3683-3690.

Goldstein L, Galski H, Fojo A, Willingham M, Lai S, Gazdar A, Pirker R, Green A, Crist W and Brodeur G. (1989). JNCI Cancer Spectrum, 81, 116-124.

Goto M, Masuda S, Saito H, Uemoto S, Kiuchi T, Tanaka K and Inui K. (2002). Pharmacogenetics, 12, 451-457.

Gottesman MM and Ambudkar SV. (2001). J. Bioenerg. Biomembr., 33, 453-458.

Gottesman MM, Fojo T and Bates SE. (2002). Nat. Rev. Cancer, 2, 48-58.

Gottesman MM, Hrycyna CA, Schoenlein PV, Germann UA and Pastan I. (1995). Annu. Rev. Genet., 29, 607-649.

Gottesman MM and Pastan I. (1988). J. Biol. Chem., 263, 12163-12166.

Gottesman MM and Pastan I. (1993). Annu. Rev. Biochem., 62, $385-427$.

Gottesman MM, Pastan I and Ambudkar SV. (1996). Curr. Opin. Genet. Dev., 6, 610-617.

Gottesman MM. (1988). J. Natl. Cancer Inst., 80, 1352-1353.

Gottesman MM. (2002). Annu. Rev. Med., 53, 615-627.

Greenberger LM. (1993). J. Biol. Chem., 268, 11417-11425.

Gribar JJ, Ramachandra M, Hrycyna CA, Dey S and Ambudkar SV. (2000). J. Membr. Biol., 173, 203-214.

Hitzl M, Drescher S, van der Kuip H, Schaffeler E, Fischer J, Schwab M, Eichelbaum M and Fromm MF. (2001). Pharmacogenetics, 11, 293-298.

Hoffmeyer S, Burk O, von Richter O, Arnold HP, Brockmoller J, Johne A, Cascorbi I, Gerloff T, Roots I, Eichelbaum M and Brinkmann U. (2000). Proc. Natl. Acad. Sci. USA, 97, 3473-3478.

Honjo Y, Hrycyna CA, Yan QW, Medina-Perez WY, Robey RW, van de Laar A, Litman T, Dean M and Bates SE. (2001). Cancer Res., 61, 6635-6639.

Horinouchi M, Sakaeda T, Nakamura T, Morita Y, Tamura T, Aoyama N, Kasuga M and Okumura K. (2002). Pharm. Res., 19, 1581-1585.

Hrycyna CA. (2001). Semin. Cell Dev. Biol., 12, 247-256.

Hrycyna CA, Ramachandra M, Ambudkar SV, Ko YH, Pedersen PL, Pastan I and Gottesman MM. (1998). J. Biol. Chem., 273, 16631-16634.

Hrycyna CA, Ramachandra M, Germann UA, Cheng PW, Pastan I and Gottesman MM. (1999). Biochemistry, 38, 13887-13899. 
Hung LW, Wang IX, Nikaido K, Liu PQ, Ames GF and Kim SH. (1998). Nature, 396, 703-707.

Illmer T, Schuler US, Thiede C, Schwarz UI, Kim RB, Gotthard S, Freund D, Schakel U, Ehninger G and Schaich M. (2002). Cancer Res., 62, 4955-4962.

Isenberg B, Thole H, Tummler B and Demmer A. (2001). Eur. J. Biochem., 268, 2629-2634.

Ito K, Suzuki H, Hirohashi T, Kume K, Shimizu T and Sugiyama Y. (1997). Am. J. Physiol., 35, G16-G22.

Ito S, Ieiri I, Tanabe M, Suzuki A, Higuchi S and Otsubo K. (2001). Pharmacogenetics, 11, 175-184.

Jedlitschky G, Burchell B and Keppler D. (2000). J. Biol. Chem., 275, 30069-30074.

Jedlitschky G, Leier I, Buchholz U, Barnouin K, Kurz G and Keppler D. (1996). Cancer Res. , 56, 988-994.

Johne A, Kopke K, Gerloff T, Mai I, Rietbrock S, Meisel C, Hoffmeyer S, Kerb R, Fromm MF, Brinkmann U, Eichelbaum M, Brockmoller J, Cascorbi I and Roots I. (2002). Clin. Pharmacol. Ther., 72, 584-594.

Johnson DR, Finch RA, Lin ZP, Zeiss CJ and Sartorelli AC. (2001). Cancer Res., 61, 1469-1476.

Karpowich N, Martsinkevich O, Millen L, Yuan YR, Dai PL, MacVey K, Thomas PJ and Hunt JF. (2001). Structure (Camb), 9, 571-586.

Kartenbeck J, Leuschner U, Mayer R and Keppler D. (1996). Hepatology, 23, 1061-1066.

Kerb R, Aynacioglu AS, Brockmoller J, Schlagenhaufer R, Bauer S, Szekeres T, Hamwi A, Fritzer-Szekeres M, Baumgartner C, Ongen HZ, Guzelbey P, Roots I and Brinkmann U. (2001a). Pharmacogenomics J., 1, 204-210.

Kerb R, Hoffmeyer S and Brinkmann U. (2001b). Pharmacogenomics, 2, 51-64.

Kerr KM, Sauna ZE and Ambudkar SV. (2001). J. Biol. Chem., 276, 8657-8664.

Kim RB, Leake BF, Choo EF, Dresser GK, Kubba SV, Schwarz UI, Taylor A, Xie HG, McKinsey J, Zhou S, Lan LB, Schuetz JD, Schuetz EG and Wilkinson GR. (2001). Clin. Pharmacol. Ther., 70, 189-199.

Kimchi-Sarfaty C, Gribar JJ and Gottesman MM. (2002). Mol. Pharmacol., 62, 1-6.

Kioka N, Tsubota J, Kakehi Y, Komano T, Gottesman MM, Pastan I and Ueda K. (1989). Biochem. Biophys. Res. Commun., 162, 224-231.

Komatani H, Kotani H, Hara Y, Nakagawa R, Matsumoto M, Arakawa H and Nishimura S. (2001). Cancer Res., 61, 2827-2832.

Konings WN and Poelarends GJ. (2002). IUBMB Life, 53, 213-218.

Kool M, van der Linden M, de Haas M, Scheffer GL, de Vree JML, Smith AJ, Jansen G, Peters GJ, Ponne N, Scheper RJ, Elferink R, Baas F and Borst P. (1999b). Proc. Natl. Acad. Sci. USA, 96, 6914-6919.

Kurata Y, Ieiri I, Kimura M, Morita T, Irie S, Urae A, Ohdo S, Ohtani H, Sawada Y, Higuchi S and Otsubo K. (2002). Clin. Pharmacol. Ther., 72, 209-219.

Laing NM, Belinsky MG, Kruh GD, Bell DW, Boyd JT, Barone L, Testa JR and Tew KD. (1998). Cancer Res., 58, 1332-1337.

Lecureur V, Sun DX, Hargrove P, Schuetz EG, Kim RB, Lan LB and Schuetz JD. (2000). Mol. Pharmacol., 57, 24-35.

Le Saux O, Urban Z, Tschuch C, Csiszar K, Bacchelli B, Quaglino D, Pasquali-Ronchetti I, Pope FM, Richards A, Terry S, Bercovitch L, de Paepe A and Boyd CD. (2000). Nat. Genet., 25, 223-227.

Leith CP, Kopecky KJ, Chen IM, Eijdems L, Slovak ML, McConnell TS, Head DR, Weick J, Grever MR, Appelbaum FR and Willman CL. (1999). Blood, 94, 1086-1099.
Lelong IH, Cardarelli CO, Gottesman MM and Pastan I. (1994). Biochemistry, 33, 8921-8929.

Leonard GD, Polgar O and Bates SE. (2002). Curr. Opin. Invest. Drugs, 3, 1652-1659.

List AF, Kopecky KJ, Willman CL, Head DR, Persons DL, Slovak ML, Dorr R, Karanes C, Hynes HE, Doroshow JH, Shurafa M and Appelbaum FR. (2001). Blood, 98, 3212-3220.

Litman T, Brangi M, Hudson E, Fetsch P, Abati A, Ross DD, Miyake K, Resau JH and Bates SE. (2000). J. Cell Sci., 113, 2011-2021.

Litman T, Druley TE, Stein WD and Bates SE. (2001). Cell Mol. Life Sci., 58, 931-959.

Liu CE, Liu PQ and Ames GFL. (1997). J. Biol. Chem., 272 , 21883-21891.

Locher KP, Lee AT and Rees DC. (2002). Science, 296, 1091-1098.

Loe DW, Deeley RG and Cole SP. (1996). Eur. J. Cancer, 32A, 945-957.

Loe DW, Deeley RG and Cole SP. (1998). Cancer Res., 58, $5130-5136$.

Loo TW and Clarke DM. (1995a). J. Biol. Chem., 270, 22957-22961.

Loo TW and Clarke DM. (1995b). J. Biol. Chem., 270, 21449-21452.

Loo TW and Clarke DM. (1999a). Biochem. Cell Biol., 77, $11-23$.

Loo TW and Clarke DM. (1999b). J. Biol. Chem., 274, 24759-24765.

Loo TW and Clarke DM. (2001a). J. Biol. Chem., 276, 31800-31805.

Loo TW and Clarke DM. (2001b). J. Biol. Chem., 276, 14972-14979.

Loo TW and Clarke DM. (2001c). J. Biol. Chem., 276, 36877-36880.

Loo TW and Clarke DM. (2002a). J. Biol. Chem., 277, 44332-44338

Loo TW and Clarke DM. (2002b). Proc. Natl. Acad. Sci. USA, 99, 3511-3516.

Maliepaard M, Scheffer GL, Faneyte IF, van Gastelen MA, Pijnenborg AC, Schinkel AH, van De Vijver MJ, Scheper RJ and Schellens JH. (2001). Cancer Res., 61, 3458-3464.

Mayer U, Wagenaar E, Beijnen JH, Smit JW, Meijer DK, van Asperen J, Borst $\mathrm{P}$ and Schinkel AH. (1996). Br. J. Pharmacol., 119, 1038-1044.

Mickley LA, Lee JS, Weng Z, Zhan Z, Alvarez M, Wilson W, Bates SE and Fojo T. (1998). Blood, 91, 1749-1756.

Mimmack ML, Gallagher MP, Pearce SR, Hyde SC, Booth IR and Higgins CF. (1989). Proc. Natl. Acad. Sci. USA, 86, 8257-8261.

Miyake K, Mickley L, Litman T, Zhan Z, Robey R, Cristensen B, Brangi M, Greenberger L, Dean M, Fojo T and Bates SE. (1999). Cancer Res., 59, 8-13.

Moriya Y, Nakamura T, Horinouchi M, Sakaeda T, Tamura T, Aoyama N, Shirakawa T, Gotoh A, Fujimoto S, Matsuo M, Kasuga M and Okumura K. (2002). Biol. Pharm. Bull., 25, 1356-1359.

Morris DI, Greenberger LM, Bruggemann EP, Cardarelli C, Gottesman MM, Pastan I and Seamon KB. (1994). Mol. Pharmacol., 46, 329-337.

Muller M, Meijer C, Zaman GJR, Borst P, Scheper RJ, Mulder NH, Devries EGE and Jansen PLM. (1994). Proc. Natl. Acad. Sci. USA, 91, 13033-13037.

Nooter K, Westerman AM, Flens MJ, Zaman GJR, Scheper RJ, vanWingerden KE, Burger $H$, Oostrum $R$, Boersma $T$, Sonneveld P, Gratama JW, Kok T, Eggermont AMM, Bosman FT and Stoter G. (1995). Clin. Cancer Res., 1, 1301-1310. 
Paulusma CC, Bosma PJ, Zaman GJR, Bakker CTM, Otter M, Scheffer GL, Scheper RJ, Borst P and Elferink R. (1996). Science, 271, 1126-1128.

Paulusma CC, Kool M, Bosma PJ, Scheffer GL, terBorg F, Scheper RJ, Tytgat GNJ, Borst P, Baas F and Elferink PJO. (1997). Hepatology, 25, 1539-1542.

Potocnik U, Glavac MR, Golouh R and Glavac D. (2001). Pflugers Arch., 442, R182-R183.

Ramachandra M, Ambudkar SV, Chen D, Hrycyna CA, Dey S, Gottesman MM and Pastan I. (1998). Biochemistry, 37, $5010-5019$

Rayment I. (1996). J. Biol. Chem., 271, 15850-15853.

Repke KR. (1982). Ann. NY Acad. Sci., 402, 272-286.

Ringpfeil F, Lebwohl MG, Christiano AM and Uitto J. (2000). Proc. Natl. Acad. Sci. USA, 97, 6001-6006.

Roberts RL, Joyce PR, Mulder RT, Begg EJ and Kennedy MA. (2002). Pharmacogenomics J., 2, 191-196.

Rosenberg MF, Velarde G, Ford RC, Martin C, Berridge G, Kerr ID, Callaghan R, Schmidlin A, Wooding C, Linton KJ and Higgins CF. (2001). EMBO J., 20, 5615-5625.

Ruetz S and Gros P. (1994). Cell, 77, 1071-1081.

Saito S, Iida A, Sekine A, Miura Y, Ogawa C, Kawauchi S, Higuchi S and Nakamura Y. (2002). J. Hum. Genet., 47, 38-50.

Sakaeda T, Nakamura T, Horinouchi M, Kakumoto M, Ohmoto N, Sakai T, Morita Y, Tamura T, Aoyama N, Hirai M, Kasuga M and Okumura K. (2001). Pharm. Res., 18, 1400-1404.

Sankaran B, Bhagat S and Senior AE. (1997). Biochemistry, 36, 6847-6853

Sarkadi B, Price EM, Boucher RC, Germann UA and Scarborough GA. (1992). J. Biol. Chem., 267, 4854- 4858.

Sauna ZE and Ambudkar SV. (2000). Proc. Natl. Acad. Sci. $U S A, 97,2515-2520$

Sauna ZE and Ambudkar SV. (2001). J. Biol. Chem., 276, $11653-11661$.

Sauna ZE, Muller M, Peng XH and Ambudkar SV. (2002). Biochemistry, 41, 13989-14000.

Sauna ZE, Smith MM, Muller M and Ambudkar SV. (2001a). J. Biol. Chem., 276, 33301-33304.

Sauna ZE, Smith MM, Muller M and Ambudkar SV. (2001b) J. Biol. Chem., 276, 21199-21208.

Sauna ZE, Smith MM, Muller M, Kerr KM and Ambudkar SV. (2001c). J. Bioenerg. Biomembr., 33, 481-491.

Schinkel AH. (1997). Semin. Cancer Biol., 8, 161-170.

Schinkel AH, Arceci RJ, Smit JJM, Wagenaar E, Baas F, Dolle M, Tsuruo T, Mechetner EB, Roninson IB and Borst P. (1993). Int. J. Cancer, 55, 478-484.

Schuetz JD, Connelly MC, Sun DX, Paibir SG, Flynn PM, Srinivas RV, Kumar A and Fridland A. (1999). Nat. Med. 5, 1048-1051.

Schwab M, Eichelbaum M and Fromm MF. (2003). Аnnu. Rev. Pharmacol. Toxicol., 43, 285-307.

Seelig A. (1998a). Eur. J. Biochem., 251, 252-261.

Seelig A. (1998b). Int. J. Clin. Pharmacol. Ther., 36, 50-54.

Senior AE. (1998). Acta. Physiol. Scand. Suppl., 643, 213-218.

Senior AE, al-Shawi MK and Urbatsch IL. (1995). FEBS Lett., 377, 285-289.

Senior AE and Bhagat S. (1998). Biochemistry, 37, 831-836.

Senior AE and Gadsby DC. (1997). Semin. Cancer Biol., 8, $143-150$.

Shapiro AB and Ling V. (1998). Eur. J. Biochem., 254, 189-193. Sharma S and Davidson AL. (2000). J. Bacteriol., 182, 6570-6576. Sharom FJ, Yu X, Chu JW and Doige CA. (1995). Biochem. $J$., 308, 381-390.

Sharom FJ, Yu X and Doige CA. (1993). J. Biol. Chem., 268, 24197-24202.

Shen DW, Pastan I and Gottesman MM. (1998). Cancer Res., 58, 268-275.
Siddiqui A, Kerb R, Weale ME, Brinkmann U, Smith A, Goldstein DB, Wood NW and Sisodiya SM. (2003). N. Engl. J. Med., 348, 1442-1448.

Siegsmund M, Brinkmann U, Schaffeler E, Weirich G, Schwab M, Eichelbaum M, Fritz P, Burk O, Decker J, Alken P, Rothenpieler U, Kerb R, Hoffmeyer S and Brauch $\mathrm{H}$. (2002). J. Am. Soc. Nephrol., 13, 1847-1854.

Sinues B, Fanlo A, Bernal ML, Mayayo E, Bello S, Rubio E and Isla D. (2003). Oncology, 64, 183-185.

Sleep JA, Hackney DD and Boyer PD. (1980). J. Biol. Chem., 255, 4094-4099.

Smit JJ, Schinkel AH, Oude Elferink RP, Groen AK, Wagenaar E, van Deemter L, Mol CA, Ottenhoff R, van der Lugt NM and van Roon MA et al. (1993). Cell, 75, 451-462.

Smith CA and Rayment I. (1996). Biochemistry, 35, 5404-5417. Strautnieks SS, Bull LN, Knisely AS, Kocoshis S, Dahl N, Arnell H, Sokal E, Dahan K, Childs S, Ling V, Tanner MS, Kagalwalla AF, Nemeth A, Pawlowska J, Baker A, MieliVergani G, Freimer NB, Gardiner RM and Thompson RJ. (1998). Nat. Genet., 20, 233-238.

Struk B, Cai L, Zach S, Chung WJJ, Lumsden A, Stumm M, Huber M, Schaen L, Kim CA, Goldsmith LA, Viljoen D, Figuera LE, Fuchs W, Munier F, Ramesar R, Hohl D, Richards R, Neldner KH and Lindpaintner K. (2000). J. Mol. Med., 78, 282-286.

Szabo K, Welker E, Bakos Muller M, Roninson I, Varadi A and Sarkadi B. (1998). J. Biol. Chem., 273, 10132-10138.

Tanabe M, Ieiri I, Nagata N, Inoue K, Ito S, Kanamori Y, Takahashi M, Kurata Y, Kigawa J, Higuchi S, Terakawa N and Otsubo K. (2001). J. Pharmacol. Exp. Ther., 297, 1137-1143.

Tang K, Ngoi SM, Gwee PC, Chua JM, Lee EJ, Chong SS and Lee CG. (2002). Pharmacogenetics, 12, 437-450.

Urbatsch IL, al-Shawi MK and Senior AE. (1994). Biochemistry, 33, 7069-7076.

Urbatsch IL, Beaudet L, Carrier I and Gros P. (1998). Biochemistry, 37, 4592-4602.

Urbatsch IL, Gimi K, Wilke-Mounts S and Senior AE. (2000a). Biochemistry, 39, 11921-11927.

Urbatsch IL, Julien M, Carrier I, Rousseau ME, Cayrol R and Gros P. (2000b). Biochemistry, 39, 14138-14149.

Urbatsch IL, Sankaran B, Bhagat S and Senior AE. (1995a). J. Biol. Chem., 270, 26956-26961.

Urbatsch IL, Sankaran B, Weber J and Senior AE. (1995b). J. Biol. Chem., 270, 19383-19390.

Volk EL, Farley KM, Wu Y, Li F, Robey RW and Schneider E. (2002). Cancer Res., 62, 5035-5040.

von Ahsen N, Richter M, Grupp C, Ringe B, Oellerich M and Armstrong VW. (2001). Clin. Chem., 47, 1048-1052.

Vulevic B, Chen ZJ, Boyd JT, Davis W, Walsh ES, Belinsky MG and Tew KD. (2001). Cancer Res., 61, 3339-3347.

Wang RX, Salem M, Yousef IM, Tuchweber B, Lam P, Childs SJ, Helgason CD, Ackerley C, Phillips MJ and Ling V. (2001). Proc.Natl. Acad. Sci. USA, 98, 2011-2016.

Wijholds J, Mol C, van Deemter L, de Haas M, Scheffer GL, Baas F, Beijnen JH, Scheper RJ, Hatse S, De Clercq E, Balzarini J and Borst P. (2000). Proc. Natl. Acad. Sci. USA, 97, 7476-7481.

Wu Q, Bounaud PY, Kuduk SD, Yang CP, Ojima I, Horwitz SB and Orr GA. (1998). Biochemistry, 37, 11272-11279.

Yamada S and Ikemoto N. (1980). J. Biol. Chem., 255, 3108-3119.

Yamauchi A, Ieiri I, Kataoka Y, Tanabe M, Nishizaki T, Oishi R, Higuchi S, Otsubo K and Sugimachi K. (2002). Transplantation, 74, 571-572.

Zhou S, Morris JJ, Barnes YX, Lan L, Schuetz JD and Sorrentino BP. (2002). Proc. Natl. Acad. Sci. USA, 99, 12339-12344. 